\title{
Plant-Derived Antimicrobial Peptides as Potential Antiviral Agents in Systemic Viral Infections
}

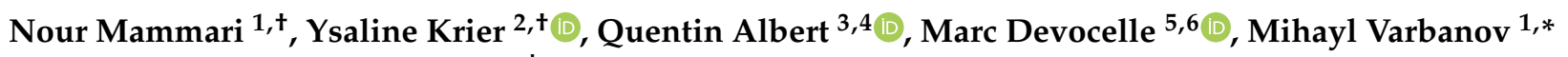 \\ and on behalf of the OEMONOM $\ddagger$ \\ 1 L2CM, Université de Lorraine, CNRS, F-54000 Nancy, France; nour.mammari@univ-lorraine.fr \\ 2 Faculté de Pharmacie, 7 Avenue de la Foret de Haye, 54505 Vandoeuvre-Les-Nancy, France; \\ ysaline.krier9@etu.univ-lorraine.fr \\ 3 Fungal Biodiversity and Biotechnology, INRAE/Aix-Marseille University, UMR1163, 13009 Marseille, France; \\ quentin.ALBERT@univ-amu.fr \\ 4 CIRM-CF, INRAE/Aix Marseille University, UMR1163, 13009 Marseille, France \\ 5 SSPC (SFI Research Centre for Pharmaceuticals), V94T9PX Limerick, Ireland; mdevocelle@rcsi.ie \\ 6 Department of Chemistry, Royal College of Surgeons in Ireland, RCSI University of Medicine and Health \\ Sciences, 123, St. Stephen's Green, D02 YN77 Dublin 2, Ireland \\ * Correspondence: mihayl.varbanov@univ-lorraine.fr \\ + The authors contributed equally to this work. \\ $\ddagger$ Membership of the OEMONOM is provided in the Acknowledgments.
}

Citation: Mammari, N.; Krier, Y.; Albert, Q.; Devocelle, M.; Varbanov, M.; on behalf of the OEMONOM. Plant-Derived Antimicrobial Peptides as Potential Antiviral Agents in Systemic Viral Infections. Pharmaceuticals 2021, 14, 774 . https://doi.org/10.3390/ph14080774

Academic Editor: Daniela De Vita

Received: 30 June 2021

Accepted: 30 July 2021

Published: 6 August 2021

Publisher's Note: MDPI stays neutral with regard to jurisdictional claims in published maps and institutional affiliations.

Copyright: (c) 2021 by the authors. Licensee MDPI, Basel, Switzerland. This article is an open access article distributed under the terms and conditions of the Creative Commons Attribution (CC BY) license (https:/ / creativecommons.org/licenses/by/ $4.0 /)$.

\begin{abstract}
Numerous studies have led to a better understanding of the mechanisms of action of viruses in systemic infections for the development of prevention strategies and very promising antiviral therapies. Viruses still remain one of the main causes of human diseases, mainly because the development of new vaccines is usually challenging and drug resistance has become an increasing concern in recent decades. Therefore, the development of potential antiviral agents remains crucial and is an unmet clinical need. One abundant source of potential therapeutic molecules are plants: they biosynthesize a myriad of compounds, including peptides which can have antimicrobial activity. Our objective is to summarize the literature on peptides with antiviral properties derived from plants and to identify key features of these peptides and their application in systemic viral infections. This literature review highlights studies including clinical trials which demonstrated that plant cyclotides have the ability to inhibit the growth of viruses causing human diseases, defensin-like peptides possess anti-HIV-1 activity, and lipid transfer proteins and some lectins exhibit a varied antimicrobial profile. To conclude, plant peptides remain interesting to explore in the context of emerging and re-emerging infectious diseases.
\end{abstract}

Keywords: antiviral peptides; systemic infection; virus; natural compounds; plants

\section{Introduction}

First-generation antiviral molecules, such as amantadine, rimantadine, vidarabine, vidarabine phosphate, acyclovir and ribavirin, have serious side effects on humans due to their poor specificity [1]. Amantadine and rimantadine are useful for the treatment and prophylaxis of viral influenza A infections [1]. Vidarabine is the first drug to have become generally available in the USA for parenteral treatment of life-threatening or debilitating herpes simplex encephalitis, neonatal herpes simplex types 1 and 2, and varicella-zoster infections. It is an adenosine analog used as a replication inhibitor which can affect not only viral deoxyribonucleic acid (DNA) polymerase, but also the eukaryotic analog [2,3]. The advance of research in this area has led to the description of better molecules. Acyclovir, the first nucleoside analog and antiviral drug, is utilized for the treatment of herpes simplex virus (HSV) infections, particularly in genital herpes, and herpes zoster in varicella-zoster virus (VZV) infections [4]. This molecule causes lower toxicity to the host when compared with previously used treatments. Systemically administered 
ribavirin and aerosolized ribavirin are indicated for treating Lassa fever and respiratory syncytial virus (RSV) pneumonia in children and infants, and influenza A infections in adults, respectively [5-7]. Unfortunately, the low efficacy of antiviral treatments is still evidenced by the ever-increasing reports of viral resistance [6].

In addition, antiviral agents, including inhibitors of viral DNA polymerase, such as the nucleoside analog ganciclovir, the nucleotide analog cidofovir, and the pyrophosphate analog Foscarnet target mostly active CMV infections [7]. All these drugs are limited in their efficacy and have dose-related toxicities against CMV virus [8].

Other antiviral strategies are used to fight emerging viral infections. Vaccination is one of the most effective methods to protect against seasonal influenza virus-related epidemics. However, seasonal vaccines vary in efficacy; they can be ineffective in the elderly population and they do not provide protection against novel strains. These strains have developed resistance to neuraminidase inhibitors and nearly complete resistance to M2 ion channel inhibitors, the latter being part of the influenza envelope surface proteins [9]. There are several combination chemotherapy treatments for human immunodeficiency virus (HIV) infection. These anti-HIV therapies have led to the development of HIV resistance to drugs. Even with combination chemotherapy, resistance is still a major problem. Nevertheless, resistance patterns tend to change over time. Recent developments of resistance to several new anti-HIV drugs have been observed, including resistance to newer non-nucleoside reverse transcriptase inhibitors, integrase inhibitors, and $\mathrm{C}-\mathrm{C}$ chemokine receptor type 5 (CCR5) antagonists (e.g., maraviroc), which block a host co-receptor. It should be noted that there are molecular differences in resistance mechanisms, even with drugs of the same class. Although advances in anti-HIV therapy continue, the virus keeps evolving and developing new mechanisms of resistance to anti-HIV drugs [10]. Indeed, the phenomenon of direct-acting antiviral drug resistance in the hepatitis $\mathrm{C}$ virus (HCV) has become increasingly alarming. This has led to considerable interest in identifying common resistance-associated mutations and in understanding the biochemical mechanisms underlying viral resistance [11,12].

In this alarming context, recent evidence reveals that some antimicrobial peptides may have activity against a broad range of viruses. Plant-derived defensive peptides have become the focus of numerous studies for their potential use as novel molecules in the treatment of human viral diseases [13]. For instance, cyclotides are a large family of plant-derived peptides that have a broad range of biological roles, including antimicrobial, anthelminthic, nematocidal, and insecticidal activities [14]. Cyclotides from different plant species have been significantly investigated for their ability to inhibit the growth of viruses that are involved in human diseases by disrupting the viral envelope [15], as in the case of HIV, influenza virus H1N1 and dengue virus (DENV). Other plant defense-related peptides may curtail human virus infections by interacting and interfering with proteins and enzymes that are fundamental for the viral replication cycle [16] Among these peptides, plant defensins have predominantly been investigated against fungal pathogens and some bacterial strains, but molecules which derive from defensin also possess the capacity to reduce the activity of HIV-1 reverse transcriptase $[16,17]$. Furthermore, a number of lectins present antiviral activity and their use has been mostly suggested as antiretroviral microbicides [18]. Lectins can bind to virions and prevent viral fusion and entry into target cells, thereby preventing infection [18]. Some of the most promising anti-HIV lectins include griffithsin (GRFT) [19], banana lectin (BanLec) [20], Artocarpus heterophyllus lectin (jacalin) [21], Canavalia ensiformis lectin [22], Galanthus nivalis (snowdrop) agglutinin-related lectins [23], Myrianthus holstii lectin [24], Narcissus pseudonarcissus lectin [25], Polygonatum cyrtonema lectin (PCL) [26], and Boodlea coacta lectin [27] among others. Based on published evidence, plant-derived peptides have antiviral activity against a wide range of human viral infections such as HIV, Middle East Respiratory Syndrome coronavirus (MERS-CoV), severe acute respiratory syndrome coronavirus (SARS-CoV), HCV, HSV-2, human papillomavirus (HPV), DENV, Ebola virus (EVD) and Alphaviruses (Table 1). The main objective of this literature review is to provide an overview of plant-derived peptides exhibiting antiviral activity on human systemic infections. 
Table 1. Antiviral activities of plant peptides.

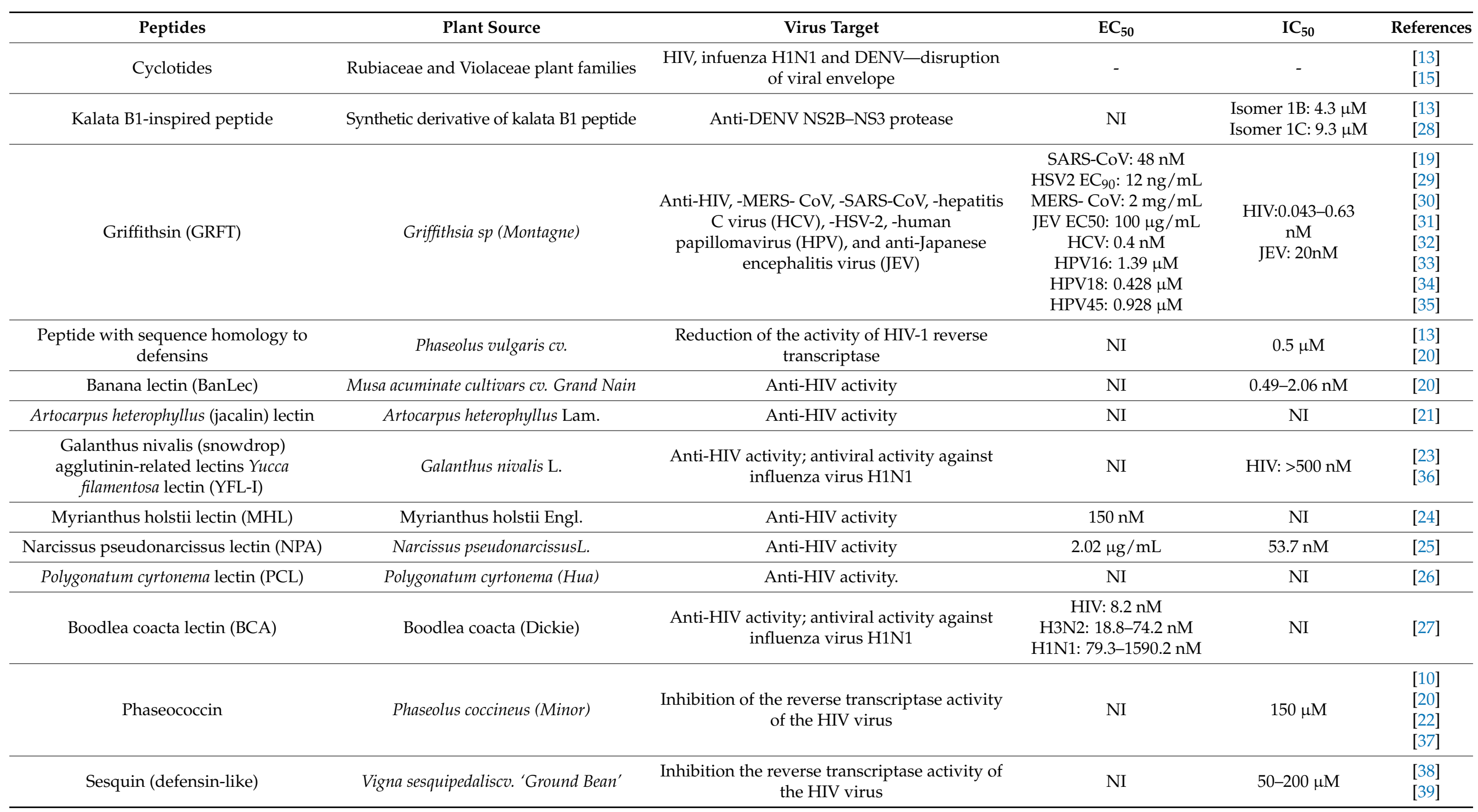


Table 1. Cont.

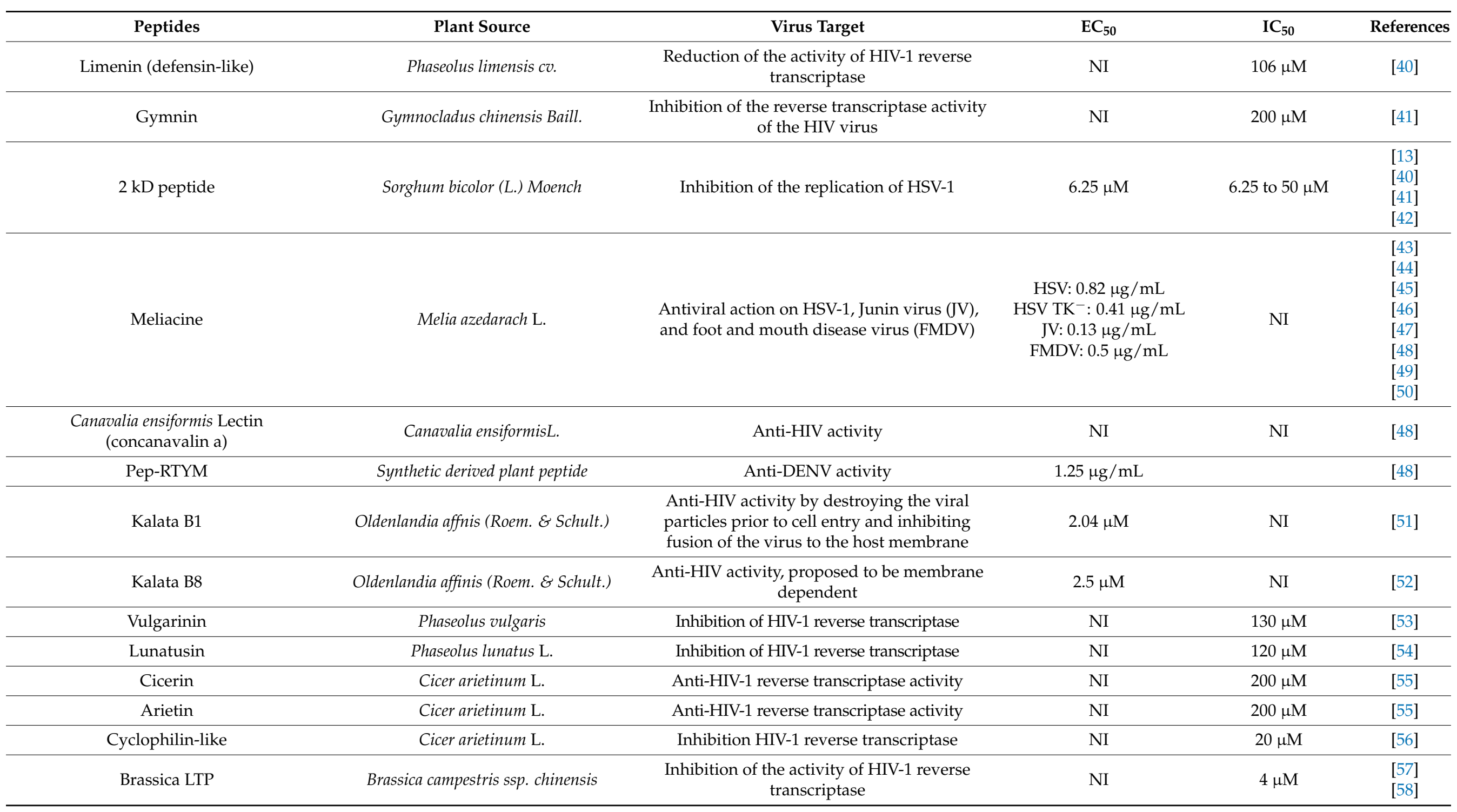


Table 1. Cont.

\begin{tabular}{|c|c|c|c|c|c|}
\hline Peptides & Plant Source & Virus Target & $\mathrm{EC}_{50}$ & $\mathrm{IC}_{50}$ & References \\
\hline Circulin A \& B & Chassalia parvifolia (K. Schum.) & Anti-HIV activity & $\mathrm{NI}$ & $40-260 \mathrm{nM}$ & [59] \\
\hline $\begin{array}{l}\text { Melibiose-binding lectin } \\
\text { Bauhinia variegata lectin }\end{array}$ & Bauhinia variegate $\mathrm{L}$. & $\begin{array}{c}\text { Inhibition of the reverse transcriptase activity } \\
\text { of the HIV virus }\end{array}$ & NI & $1.02 \mu \mathrm{M}$ & {$[60]$} \\
\hline Lectin (NICTABA) & Nicotiana tabacum var. Samsun NN & Anti-HIV activity & $0.023-0.28 \mathrm{mM}$ & NI & [61] \\
\hline Cycloviolacin VY1 and VY5 & Viola yedoensis (Makino) & $\begin{array}{c}\text { Anti-HIV activity } \\
\text { Anti-influenza A H1N1 virus }\end{array}$ & NI & $2.27 \mathrm{mg} / \mathrm{mL}$ & {$[62]$} \\
\hline $\begin{array}{l}\text { Fetuin-binding peptide } \\
\text { (lipid transfer proteins-LTP) }\end{array}$ & Narcissus tazetta var.chinensis & $\begin{array}{l}\text { Inhibition of RSV and the cytopathic effect } \\
\text { induced by influenza A (H1N1) virus }\end{array}$ & $\begin{array}{l}\text { H1N1: } 4.47 \mu \mathrm{g} / \mathrm{mL} \\
\text { RSV: } 50 \mu \mathrm{g} / \mathrm{mL} \\
\text { (final C) }\end{array}$ & NI & $\begin{array}{l}{[63]} \\
{[64]}\end{array}$ \\
\hline Narcissus tazetta lectin [NTL] & Narcissus tazetta var.chinensis & $\begin{array}{c}\text { Inhibition of RSV and the cytopathic effect } \\
\text { induced by influenza A (H1N1) virus }\end{array}$ & $\begin{array}{l}\text { RSV: } 2.30 \mu \mathrm{g} / \mathrm{mL} \\
\text { H1N1: } 0.20 \mu \mathrm{g} / \mathrm{mL}\end{array}$ & NI & {$[65]$} \\
\hline Peptide 2 and 4 & Acacia catechu (L.f.) Willd & Anti-DENV & $6.25 \mu \mathrm{M}$ & $15.25 \mu \mathrm{M}$ & [66] \\
\hline Knottins Alstotides (As1) & Alstonia scholaris Linn. R. Br. & $\begin{array}{c}\text { Inhibition of the early phase of infectious } \\
\text { bronchitis (IBV) (binds to IBV spike) virus and } \\
\text { DENV infection }\end{array}$ & $90 \mu \mathrm{M}$ & NI & $\begin{array}{l}{[67]} \\
{[68]}\end{array}$ \\
\hline Tamarindus indica lectin (TCLL) & Tamarindus indica L. & $\begin{array}{c}\text { Anti-alphaviruses } \\
\text { (chikungunya viral infection) }\end{array}$ & $>100 \mu \mathrm{M}$ & $\mathrm{N}$ & [69] \\
\hline Lectins & Aspidistra elatior (Blume) & Antiviral action on Coxsackie virus B4 and RSV & $4 \mu \mathrm{g} / \mathrm{mL}$ & $100 \mu \mathrm{g} / \mathrm{mL}$ & [70] \\
\hline Engineered banana lectin (BanLec) & Synthetic derived plant peptide & $\begin{array}{l}\text { Antiviral activity against Ebola virus disease } \\
\text { (EVD) }\end{array}$ & $\mathrm{NI}$ & $1-6 \mu \mathrm{M}$ & [71] \\
\hline
\end{tabular}




\section{Plant-Derived Antiviral Peptides (AVP) against DNA Viruses}

\subsection{Herpes Simplex Virus 1 and 2 (HSV)}

In 2016, more than 3.7 billion people under 50 years of age were infected by herpes simplex virus-1 (HSV-1) and almost 491 million people between the ages of 15 and 49 were infected by herpes simplex virus-2 (HSV-2) [37]. After a primary severe infection, these two viruses establish latency into sensory ganglia and cause latent infections and reactivations leading to cutaneous, oral or genital herpes, keratitis, conjunctivitis and encephalitis, thus affecting quality of life. No curative treatment is currently available [38]. The lipid bilayer envelope with glycoproteins of the viral particle protects the protein matrix called tegument, which protects, in turn, the 162 capsomeres of the icosahedral capsid [38]. Inside, the viral genome consists of a double-stranded DNA core encoding many enzymes, with more than 80 proteins and 90 transcriptional units for HSV-1 alone [38]. Replication and assembly of each new viral particle generation result in host cell death [38]. Prevention and prophylaxis are the main therapeutic strategies based on the use of microbicides and vaccines, along with symptomatic treatment [39].

Isolated from Sorghum bicolor seeds (Poaceae family-mostly found in Africa [40]), $2 \mathrm{kD}$ peptide is a cationic, amphiphatic peptide that exerts a HSV-1 virucidal activity by targeting viral replication cycles [41]. Even if its mechanisms of action are not perfectly understood, this peptide seems able to interact with viral envelope proteins by binding or masking them [41]. One study explained that after inoculation of Vero cells with HSV-1, the peptide showed a dose-dependent action by reducing the virus replication by $40-90 \%$ [42] The half maximal effective concentration of the peptide $\left(\mathrm{EC}_{50}\right)$ is $6.25 \mu \mathrm{M}$, the $90 \%$ maximal effective concentration $\left(\mathrm{EC}_{90}\right.$ ) value is $15.25 \mu \mathrm{M}$ and the value of half maximal inhibitory concentration of the peptide required for inhibition of infection $\left(\mathrm{IC}_{50}\right)$ is $250 \mu \mathrm{M}$ [42]. This peptide also showed a dose-dependent action against HSV-1-induced cytopathic effects. Its inoculation in Vero cells before infection with HSV-1 resulted in an $\mathrm{EC}_{50}$ value of $12.25 \mu \mathrm{M}$, whereas values of $\mathrm{EC}_{50}$ are $6.25 \mu \mathrm{M}$ when the peptide is inoculated on cells during and after infection with HSV-1. Other experiments regarding incubation of the peptide with other viruses led to the conclusion that this peptide may also have an in vitro prophylactic effect against HIV-1 [42].

Some defensins use the same supposed mechanism as the previous peptide: these small (around 50 amino-acids, at maximum) cationic and cysteine-rich peptides protect the host by binding viral glycoproteins before their interaction with host cells [42,43].

Meliacine is a glycopeptide isolated from leaves of Melia azedarach L., also called "Chinaberry tree", from the Meliaceae family-native to Asia, but also found in America, Northern Australia, Africa and Southern Europe [43]. Meliacine targets the replication cycle of HSV-1 and, more specifically, polypeptides participating in viral DNA synthesis and in the assembly of viral nucleocapsids in the infected cell. The treatment of HSV-1-infected Vero cells with $50 \mu \mathrm{g} / \mathrm{mL}$ of meliacine leads to a reduction of $45 \%$ in the quantity of the viral DNA, disruption of the spread of viral particles and of the proportion of mature virus particles $[44,45]$.

In an in vivo study, the peptide was administrated topically during 4 days to Balb/c mice infected by HSV-1 inducing a herpetic stromal keratitis. The results showed that meliacine significantly reduced histological damage to the cornea and reduced clinical signs. Compared to control mice, the quantity of isolated virus was 2-fold lower. No toxic effects to host cells due to this peptide have been identified [45]. Another study confirms the efficiency of meliacine in inhibition of the viral replication of a wild-type HSV and a thymidine kinase-deficient HSV- 1 mutant $\left(\mathrm{TK}^{-}\right)\left(\mathrm{EC}_{50}\right.$ of 0.82 and $0.41 \mu \mathrm{g} / \mathrm{mL}$, respectively), without alterations to host cell viability, and suggests the use of this peptide, and the action of acyclovir, for a synergistic effect against HSV-1 replication [46].

The action of this peptide has been tested against HSV-2 with topical administration of $15.00 \pm 1.93 \mathrm{mg} / \mathrm{mL}$ of meliacine to Balb/c mice infected by HSV-2 inducing a genital herpetic infection. Results showed that meliacine increased host survival, and reduced by 
$90 \%$ the severity of clinical symptoms and the presence of viral particles in vaginal fluids. It is noteworthy that the composition of this fluid was different from the one of untreated mice, as it presented increasing amounts of IFN-gamma (2550 $\pm 63 \mathrm{pg} / \mathrm{mL})$ and TNF-alpha (from $7 \pm 0.9 \mathrm{ng} / \mathrm{mL}$ to $12.15 \pm 0.92 \mathrm{ng} / \mathrm{mL}$ ), cytokines implicated in inflammation $[47,48]$. This ability to increase cytokine production has been confirmed by another study using $56 \mu \mathrm{g} / \mathrm{mL}$ of meliacine applied in lipopolysaccharide-producing Escherichia coli bacterial infection $[47,48]$.

\subsection{Human PapillomaVirus (HPV)}

Human papilloma viruses (HPV) are a small group of non-enveloped viruses belonging to the Papillomaviridae family. The viral particles consist of a genome in the form of a circular double-stranded DNA. HPV infection remains the second most frequently occurring cause of cervical cancer in women worldwide, with an estimated 291 million HPV-positive women in 2007 [72]. The incidence and prevalence of this pathology vary mostly on factors including HPV genotype [73]. So far, there only preventative HPV vaccines that have been endorsed by the United States Food and Drug Administration (FDA), namely Cervarix ${ }^{\circledR}$ and Gardasil ${ }^{\circledR}$ These vaccines are accessible for early prophylaxis of infection with common cancer-causing HPV types, but local and systemic treatments are still under review [74].

The preclinical evaluation of griffithsin (GRFT), a lectin isolated from the red marine alga Griffithsia sp., has been identified to be an antiviral compound against human papillomavirus (HPV) in vitro with an $\mathrm{EC}_{50} 35.1 \mu \mathrm{g} / \mathrm{mL}(1.39 \mu \mathrm{M})$ [29]. Another study evaluated the anti-HPV activity of GRFT and found an $\mathrm{EC}_{50}$ of $10.8 \mu \mathrm{g} / \mathrm{mL}(0.428 \mu \mathrm{M})$ for HPV18, and an $\mathrm{EC}_{50}$ of $23.4 \mu \mathrm{g} / \mathrm{mL}(0.928 \mu \mathrm{M})$ for HPV45 [30].

\section{Plant-Derived Antiviral Peptides against RNA Viruses}

\subsection{Human Immunodeficiency Virus (HIV)}

HIV-1 and HIV-2 belong to the family of Retroviridae and genus. They are enveloped RNA viruses and rely on the enzyme reverse transcriptase to transcribe their genome from RNA into DNA, which can then be integrated into the host's genome with an integrase enzyme, becoming part of the cellular DNA and replicating with it [75].

HIV was first isolated in 1983. Transmission can be horizontal (blood, sexual transmission) or vertical (mother to child through pregnancy). The virus targets mainly T CD4+ cells and lead to AIDS (acquired immune deficiency syndrome) when their count is profoundly reduced.

Human immunodeficiency virus (HIV) infection is an important contributor to global disease burden and a leading cause of death. In 2020, the estimated number of persons living with HIV in the world was close to 38 million people; a total of 690,000 people have died from HIV infection and about 1.5 million have been infected this same year [76]. This virus, which targets the immune system, leads to immunodeficiencies and consequently to opportunistic infections and cancers. Due to greater understandings of the virus's replication cycle, current therapeutic strategies have led to better quality of life for patients, but there is still no effective cure for HIV infection. However, plant peptides could be a novel strategy of HIV infection treatment [77].

Cyclotides belong to a large family of circular, amphipathic, plant-derived peptides characterized by a head-to-tail cyclic backbone and three conserved disulfide bonds. They are numerous and diversified in Violaceae, Rubiaceae, Curcurbitaceae, Fabaceae and Solanaceae [14]. This family presents a number of pharmaceutical potentials and is particularly famous for its quantity of peptides presenting with anti-HIV activity [78]. The position of the disulfide bonds is conserved along the peptide's sequences, but their topology or activity defines three subfamilies: Möbius, bracelet, and trypsin inhibitors. Their cyclic structure, which provides chemical stability in acidic, high temperature conditions and protection against biological degradation, may allow a per os administration. Cyclotides target HIV through interactions with the viral envelope and more specifically by disrupting 
the viral lipid envelope. This leads to the formation of pores, the leakage of components and the destruction of viral particles before their entry into host cells: cyclotides could prevent fusion between HIV and host cells (Figure 1) [47,51,79].

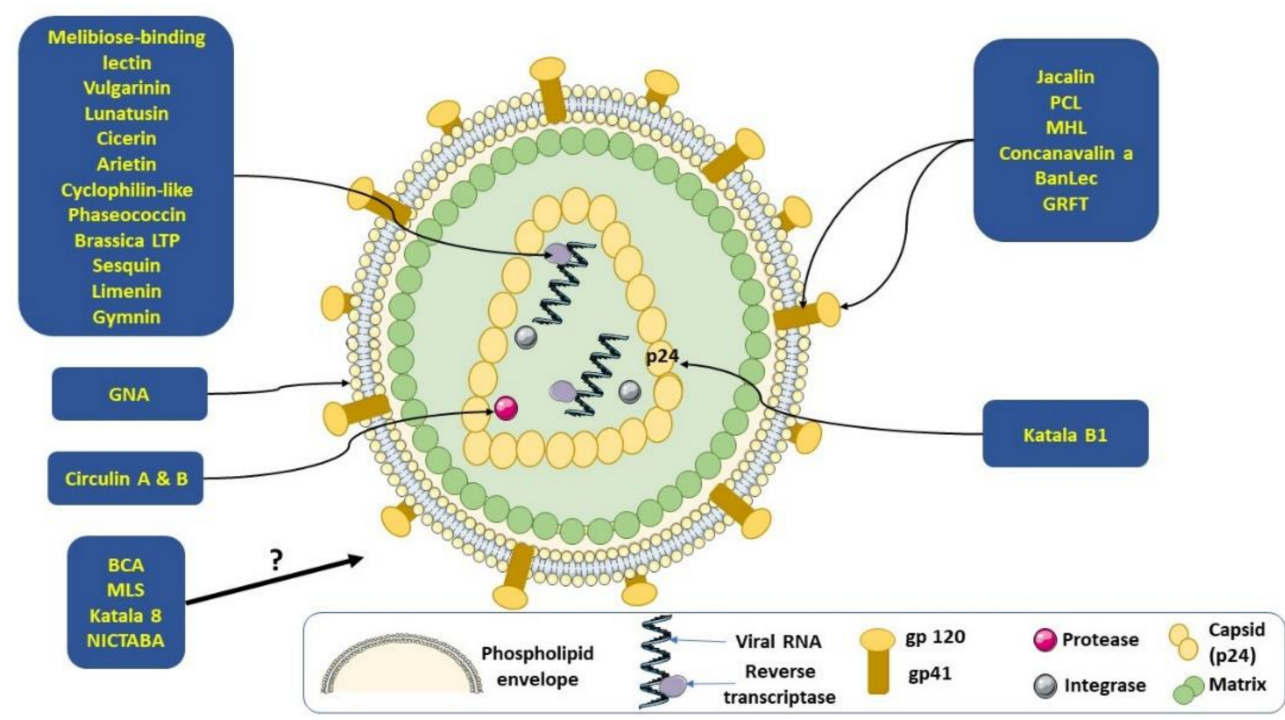

Figure 1. Melibiose-binding lectin, vulgarinin, lunatusin, cicerin, arietin, cyclophilin-like, phaseococcin, brassica LTP, sesquin, limenin, and gymnin inhibit the reverse transcriptase of HIV; circulin A \& B inhibit the protease of HIV; katala B1 inhibits p24 capsid protein; jacalin, PCL, MHL, concanavalin a, BanLec, and GRFT inhibit HIV attachment through blocking the viral receptor (gp120/gp41); GNA targets the envelope glycoproteins of HIV-1; BCA, MLS, katala 8, and NICTABA possess anti-HIV activity but the mechanism is not yet elucidated.

Kalata B1, which is the most studied and known Möbius cyclotide isolated from leaves of Oldenlandia affinis, presents with viricidal activity against HIV. This conclusion is the result of a study in which the peptide had been in contact with two HIV-1 strains (NL4.3/92RW016 using CXCR4 as a co-receptor and a clade A strain using CXCR5 as a coreceptor) at different concentrations. The results showed a $50 \%$ reduction in viral infectivity of TZM-bl cells compared with the untreated virus. The half viral infectivity $\left(\mathrm{VC}_{50}\right)$ is $2.04 \mu \mathrm{M}$ for NL 4.3 and $4.54 \mu \mathrm{M}$ for Clade A. Another study about the ability of the peptide to disturb HIV-1 particles (strain NL4.3) indicated a decrease in the capsid protein p24 [51]. To evaluate if Kalata B1 targets the membrane to disrupt HIV-1, NL4.3 virus particles were treated with this peptide and results showed a decrease in the viral capsid protein (p24), indicating that Kalata B1 targets the HIV membrane via peptide-lipid interactions (Figure 1) [80].

Kalata B8, a new cyclotide isolated from Oldenlandia affinis, provides anti-HIV activity. Its structure appears to be a hybrid between the two major subfamilies of cyclotides. Specifically, loops 2 and 3 of kalata B8 resemble those found in kalata B1 and B2. To determine its antiviral activity, anti-HIV assays were performed in HIV-infected cultured human T-lymphoblast (CEM-SS) cells using the highest $4.5 \mu \mathrm{M}$ concentration. Results showed that kalata B8 inhibited the cytopathic effects of HIV-1 infected CEM-SS cells with an antiviral cytoprotective concentration $\left(\mathrm{EC}_{50}\right)$ of $2.5 \mu \mathrm{M}$, while the cytotoxic concentration for host cells $\left(\mathrm{CC}_{50}\right)$ was higher than $11 \mu \mathrm{M}$ (Figure 1) [52].

Some plant-derived peptides act by inhibiting HIV-1 reverse transcriptase: among them can be cited the $7 \mathrm{kDa}$ peptides vulgarinin from haricot beans (Phaseolus vulgaris), with an $\mathrm{IC}_{50}$ of $130 \mu \mathrm{M}$ [53]; lunatusin isolated from the seeds of the Chinese lima bean (Phaseolus lunatus L.), with an $\mathrm{IC}_{50}$ of $120 \mu \mathrm{M}$ [54]; and cicerin and arietin, isolated from chickpea seeds (Cicer arietinum), with a molecular weight of approximately 8.2 and $5.6 \mathrm{kDa}$, respectively. Both peptides possess inhibitory activity toward HIV-1 reverse transcriptase when tested at $200 \mu \mathrm{M}$ (IC $200 \mu \mathrm{M}$ ) [55]. In addition, cyclophilin-like peptide, isolated 
from chickpea seeds (Cicer arietinum) and characterized by a molecular weight of $18 \mathrm{kDa}$, is able to inhibit HIV-1 reverse transcriptase with an $\mathrm{IC}_{50}$ of about $20 \mu \mathrm{M}$ [56]. Phaseococcin (5422 Da), isolated from small scarlet runner beans of Phaseolus coccineus, possesses anti-HIV activity with an $\mathrm{IC}_{50}$ of about $150 \mu \mathrm{M}$ (Figure 1) [81].

Peptide brassica (LPT) isolated from Brassica compestris exhibits an anti-HIV-1 reverse transcriptase activity with an $\mathrm{IC}_{50}$ of $4 \mu \mathrm{M}[81,82]$. Two peptides without specific names are represented in this list: one of $6 \mathrm{kDa}$ is purified from baby lima beans with an $\mathrm{IC}_{50}$ of $4 \mu \mathrm{M}$ [57] and the other one of $10 \mathrm{kDa}$ originates from the coconut with an $\mathrm{IC}_{50}$ value of $52.5 \mu \mathrm{M}$ (Figure 1) [58].

The defensin-like antimicrobial peptide sesquin $(7 \mathrm{kDa})$, highly homologous to defensin, was isolated from ground beans (Vigna sesquipedalis). An inhibitory activity on HIV-1 reverse transcriptase was determined for this defensin-like peptide, with and $\mathrm{IC}_{50}$ between 50 to $200 \mu \mathrm{M}$ (Figure 1) [83]. Another defensin peptide (5443 Da) without specific designation, isolated from the seeds of the purple pole bean (Phaseolus vulgaris) and displaying an $\mathrm{IC}_{50}$ value of about $0.5 \pm 0.1 \mu \mathrm{M}$, proved to be significantly promising compared to other defensins, presenting an average $\mathrm{IC}_{50}$ value superior to $40 \mu \mathrm{M}$ [84]. Some other defensin-like peptides inhibit HIV-1 reverse transcriptase. This is the case for gymnin $(6.5 \mathrm{kDa})$, isolated from the seeds of the Yunnan bean and presenting an $\mathrm{IC}_{50}$ value of $200 \mu \mathrm{M}$ [85], and limenin $(6.5 \mathrm{kDa})$, isolated from the seeds of the shelf bean and presenting an $\mathrm{IC}_{50}$ value of $106 \mu \mathrm{M}$ (Figure 1) [36].

Evidence proved that two macrocyclic peptides named cirulin A and cirulin B, isolated from Chassalia parviflora (Rubiaceae), have the capacity to inhibit HIV protease. For both compounds, the antiviral cytoprotective concentrations ranged from about 40 to $260 \mathrm{nM}$ (Figure 1) [59].

Another peptide family, lectins, which are sugar binding proteins that can trigger signals through cell surface molecules involved in lymphocyte activation, has proved its anti-HIV activity [18]. It has been shown that jacalin, a $50 \mathrm{kDa}$ plant lectin purified from jackfruit seeds (Artocarpus heterophyllus), has potent antiviral effects and inhibits the HIV-I life cycle at a step before fusion, and also binds CD4 T lymphocytes [21]. Canavalia ensiformis lectin, another peptide that belongs to the same family, has the ability to bind gp120 from HIV-1 and HIV-2 isolates, and consequently block the HIV replication cycle [86]. Mannose-specific lectins (MSLs) isolated from the bulbs of fifteen wild Narcissus species were assayed for their HIV-1 infection inhibitory activity in MT-4 cells. It has been shown that this kind of lectin exhibits anti-HIV activity with an $\mathrm{EC}_{50}$ of $2.02 \mu \mathrm{g} / \mathrm{mL}$ at $53.7 \mathrm{nM}$ [25]. The sensitivity of Galanthus nivalis lectin (GNA) studied against the envelope glycoproteins of HIV-1 showed that GNA could be a potent anti-HIV agent, with $\mathrm{IC}_{50}$ values ranging between $1.3 \pm 0.2$ to $>500 \mathrm{nM}$ (Figure 1) [87]. Polygonatum cyrtonema lectin (PCL), a novel anti-HIV mannose-binding lectin from the Galanthus nivalis agglutinin (GNA)-related lectin family, is characterized by its unique super structure of the PCL mannoside complex. This structure may destabilize the binding of the HIV surface envelop glycoprotein gp120 to specific receptors on cell membranes and block viral fusion [26]. Myrianthus holstii lectin (MHL), extracted from the African plant Myrianthus holstii, has anti-HIV activity, with an $\mathrm{EC}_{50}$ value of $150 \mathrm{nM}$. This lectin binds a soluble form of the viral envelope protein gp120 [24]. In vitro assays of potent anti-HIV activity of the complete amino acid sequence of a lectin isolated from the green alga Boodlea coacta (BCA) was determined by conventional MTT assay using MT-4 cells. Data showed that BCA inhibited HIV-1 infection dose-dependently, with an $\mathrm{EC}_{50}$ of $8.2 \mathrm{nM}$ [27]. A dimeric 64-kDa melibiose-binding lectin was isolated from the seeds of Bauhinia variegate and manifested potent inhibition of HIV-1 reverse transcriptase activity with a low $\mathrm{IC}_{50}$ of $1.02 \mu \mathrm{M}$ [60]. A unique lectin (NICTABA) produced by the tobacco plant, Nicotiana tabacum, has been evaluated for its inhibitory activity against HIV using cell-line-adapted HIV-1 strains. Results revealed that NICTABA was able to inhibit infection by HIV strains with an $\mathrm{EC}_{50}$ in the lower micromolar range $\left(\mathrm{EC}_{50} 0.023-0.28 \mathrm{mM}\right.$ ) [61]. Banana lectin (BanLec) is a jacalin-related lectin isolated from the banana fruit, Musa acuminata. This lectin binds to high-mannose carbohydrate structures, 
the same as those found in viruses containing glycosylated envelope proteins such as HIV-1. It was demonstrated that BanLec might inhibit HIV-1 and laboratory-adapted HIV-1 isolates of different tropisms and subtypes through binding of the glycosylated HIV-1 envelope protein gp120, thus blocking entry of the virus into the cell. This lectin possesses potent anti-HIV activity, with $\mathrm{IC}_{50}$ values ranging between $2.06 \mathrm{nM}$ to $0.49 \mathrm{nM}$ (Figure 1) [20].

Studies carried out on peptides extracted from aquatic plants have shown the potential antiviral activity of these compounds. Griffithsin (GRFT), a novel anti-HIV protein, was isolated from an aqueous extract of the red alga Griffithsia sp. GRFT displayed antiviral activity against laboratory strains and primary isolates of HIV-1 with $\mathrm{EC}_{50}$ values ranging between 0.043 to $0.63 \mathrm{nM}$. GRFT aborts cell-to-cell fusion and transmission of HIV-1 infection by blocking gp120 binding to receptor-expressing cells and binds to viral surface glycoproteins (gp120, gp41, and gp160) in a glycosylation-dependent manner (Figure 1) [31].

\subsection{Influenza Strain A H1N1}

The influenza A H1N1 virus belongs to the family Orthomyxoviridae, and is an enveloped virus and negative-sense RNA virus. Type A is one of the three major types of influenza viruses, which also include types B and C. Type A is divided into subtypes, which are differentiated mainly on the basis of two surface antigens: hemagglutinin $(\mathrm{H})$ and neuraminidase $(\mathrm{N})$. The H1N1 subtype is further differentiated into strains based on minor variations in RNA sequence [88].

Influenza virus, subtype H1N1, causes moderate to severe respiratory disease and affects all age groups. It was declared as pandemic by the WHO in 2009 [89]. Among influenza A viruses that infect humans, three major subtypes of hemagglutinins ( $\mathrm{H} 1, \mathrm{H} 2$, and $\mathrm{H} 3$ ) and two subtypes of neuraminidases (N1 and N2) have been described [90]. The influenza 1 virus has a significant ability to undergo periodic changes in the antigenic characteristics of their envelope glycoproteins, the hemagglutinin and the neuraminidase, and consequently, it presents a novel circulating strain resist to eventual vaccination as well as treatments [91]. The only two classes of antiviral drugs against influenza are the adamantane and neuraminidase inhibitors, for which there are already described cases of resistance [91]. Natural remedies and plant peptides have been described to have antiviral activity against the influenza H1N1 virus.

Cyclotides from different plant species have been significantly investigated for their ability to inhibit human viruses, including influenza H1N1 [13]. A cyclotide isolated from the whole plant of Viola yedoensis, cycloviolacin VY1, was previously reported as having antiviral activity against the $\mathrm{H} 1 \mathrm{~N} 1$ virus. Experimentation showed that the $\mathrm{IC}_{50}$ value of cycloviolacin VY1 against influenza A H1N1 virus was $2.27 \pm 0.20 \mathrm{mg} / \mathrm{mL}$. This was the first cyclotide described as an anti-influenza A agent against the H1N1 virus [62].

In addition, it was described that a blood glycoprotein fetuin-binding peptide LTP, with a molecular mass of about $9 \mathrm{kDa}$, isolated from the bulbs of the Chinese daffodil, Narcissus tazetta var. chinensis L., has the ability to inhibit influenza A H1N1 virus replication. Studies suggest that this antiviral activity can be related to the capacity of fetuin to bind the virus and consequently to block the neuraminidase in the viral envelope [63]. The half maximal effective concentration of this peptide LTP $\left(\mathrm{EC}_{50}\right)$ that inhibits $50 \%$ of the replication of influenza A H1N1 virus is about $4.47 \mathrm{mg} / \mathrm{mL}$, determined by MTT assay, a colorimetric assay for assessing cell metabolic activity and viability, used in this study to evaluate the survival rate of Madin-Darby Canine Kidney (MDCK) cells [64]. Another Narcissus tazetta lectin (NTL) exhibits evenly strong antiviral properties against influenza A (H1N1) with $\mathrm{IC}_{50}$ values ranging between $0.20 \mu \mathrm{g} / \mathrm{mL}$ to $1.33 \mu \mathrm{g} / \mathrm{mL}$ in a dose-dependent manner. It is expected that the antiviral mechanism of NTL against influenza A virus is achieved mainly through acting on the early stage of the viral cycle of influenza A (H1N1) virus [65]. 
Yucca filamentosa lectin (YFL-I) is part of the Galanthus nivalis agglutinin (GNA)-related lectin family, and also exhibits anti-influenza activity. Accordingly, per the results of the study of Xi et al., Yucca filamentosa lectin, as GNA-related lectins, could prevent influenza virus infection. YFL-I has a higher affinity than influenza hemagglutinin to bind host cell sialic acid, and this may block the early stages of viral entry and infection [23].

A lectin isolated from the green alga Boodlea coacta (BCA) showed its potent activity against different influenza virus strains by directly binding to viral envelope hemagglutinin. Experimentations were made on MDCK cells by the neutral red dye uptake assay, which provides a quantitative estimation of the number of viable cells in a culture. Ten influenza A virus strains, including laboratory-adapted strains as well as one influenza virus B strain, were used in the study to determine the antiviral activity of BCA. Data showed that BCA has a stronger capacity to inhibit $\mathrm{H} 3 \mathrm{~N} 2$ subtypes at $\mathrm{EC}_{50}$ values of $18.8-74.2 \mathrm{nM}$, while the antiviral activity of BCA was much weaker against $\mathrm{H} 1 \mathrm{~N} 1$ subtypes demonstrated by the $\mathrm{EC}_{50}$ values of 79.3-1590.2 $\mathrm{nM}$. The clinical isolates of the pandemic strain, swine-origin influenza virus, A/Oita/OU1 P3-3/09 (H1N1), were also susceptible to BCA. This study also determined that $\mathrm{BCA}$ directly binds to the oligosaccharide on the influenza envelope glycoprotein hemagglutinin. For that, enzyme-linked immunosorbent assays (ELISA) were performed using an influenza vaccine preparation, which contains hemagglutinin of A/California/7/09 (H1N1), A/Victoria/210/09 (H3N2), and B/Brisbane/60/08 influenza strains. Results indicate that H3N2 subtypes are more sensitive to 1-2-linked mannosebinding lectins than H1N1 subtypes [27].

\subsection{Junin Hemorrhagic Fever Virus (JHFV)}

JHFV is an enveloped virus containing two single-stranded RNA molecules. Virions are pleomorphic; particles vary in diameter from between 40 to $200 \mathrm{~nm}$. Around 5 million humans run the risk of being infected by the Junin virus, which causes a hemorrhagic fever. Described for the first time in the 1950s, recent progress on JHFV-induced pathology and on the virus itself is leading to the development of potential vaccines and drugs [92].

The meliacine peptide, described above for its anti HSV-activity, is also efficient against the Junin hemorrhagic fever virus. It targets the early step of virus infection by preventing the uncoating step, disturbs the release of viral particles and interferes with the low-pH-induced fusion of infected cells [49].

\subsection{Respiratory Syncytial Virus (RSV)}

Respiratory syncytial virus (RSV) is a member of the Paramyxoviridae family and contains a single-stranded negative-sense RNA genome. The RSV genome encodes for 11 structural and nonstructural proteins, including the nucleoprotein, phosphoprotein and RNA-dependent RNA polymerase encapsulate the viral RNA. This structure forms the minimal replication machinery. RSV possesses three integral membrane proteins: the receptor attachment glycoprotein, the fusion protein, and a short hydrophobic protein [93].

In 2017, according to the World Health Organization (WHO), RSV remains the most common cause of lower respiratory tract infection in neonates and young infants, especially in low- and middle-income countries [94]. Nowadays, prevention in premature or severely immunosuppressed infants relies on palivizumab, a monoclonal antibody with a rather high risk of side effects (cardiac and pulmonary) [94,95]. Ribavirin's application in RSV infection has not showed a significant advantage in clinical usage (decrease in mortality, in hospitalization duration, intensive care unit admission and in mechanical ventilation needs) and is no longer recommended $[95,96]$. The RSV vaccine roadmap priority targets immunization of young infants [96]. Effectively, it is supposed that young children ( $<10$ years old) could play a major role in RSV propagation [97]. In developed countries, RSV also infects young infants ( $<3$ months years old), with a seasonal peak during November and December [98]. However, RSV infection can equally occur in elderly individuals (especially in long term care facilities), suggesting that RSV can be an important cause of morbidity [94]. As of 2021, no vaccine has yet been developed [99]. 
Development of new RSV disease treatments should focus on improvement in symptoms, clinical expression reduction, and transmission reduction. Several new potential drugs have been evaluated in clinical trials (phase 1 and 2), but it seems that none of them are from plant origin. For example, RSV521 or sisunatovir showed $63 \%$ virus load reduction at the dose of $350 \mathrm{mg}$ per os and seems promising. It was developed by drug design optimization $[100,101]$. Ziresovir is currently undergoing a phase 2 double-blind clinical trial in the adult population [101]. However, the need for new preventive and therapeutic drugs against RSV infections remains strong. Vaccination remains the main objective against RSV pandemics. There are 3 protein-based vaccine candidates (fusion inhibitors) in phase 3 clinical trials so far [102]. Two are from GlaxoSmithKline (one for maternal prevention and one for elderly people), while the third one is from Pfizer and targets maternal prevention [102].

Other biological resources and strategies, such as plant peptide antivirals, may help to control the spread of this disease [99]. However, regarding the natural products obtained from plants, few molecules have been identified so far. Fetuin-binding peptide LTP, which inhibits replication of H1N1 virus, also showed antiviral activity against RSV [63,64]. This study was performed in RSV-infected HEp-2 cell monolayers; antiviral assay demonstrated that LPT peptide could reduce $37.55 \%$ of plaque formation by RSV at a final concentration of $50 \mu \mathrm{g} / \mathrm{mL}$ [64]. Furthermore, it could block the entrance of the RSV in host cells [64]. Narcissus tazetta lectin (NTL) also showed the capacity to inhibit plaque formation by the human RSV with an $\mathrm{IC}_{50}$ of $2.30 \mu \mathrm{g} / \mathrm{mL}$ during the whole viral infection cycle [65].

\subsection{Flavivirus $(F V)$}

The genus flaviviruses, from the Flaviviridae family (flavus is the latin word for yellow), are positive single-strand RNA viruses that infect mammals. The genome (about $10 \mathrm{~kb}$ ) codes 3 structural proteins (C, prM, E) and 7 nonstructural proteins (NS1 to NS7). The viral particle size is about $50 \mathrm{~nm}$. Yellow fever virus (YFV), which has given the name to the genus, was first discovered in the 1920s. It was followed by the West Nile virus (WNV), Japan encephalitis virus (JEV), tick-borne encephalitis virus (TBEV), DENV and ZIKV, which are all part of the flaviviruses. They represent a major health concern all over the world, causing emergent and re-emergent infectious diseases. Mosquito species as Aedes sp. and Culex sp. are the main vectors, except for TBEV [103].

Flu-like syndromes are the predominant symptoms. However, complications (articular, encephalitis, neuropathology, and organ failure) may occur and lead to high death rates. To date, no specific treatment is available in most cases. Treatment relies mostly on nursing, hydration, and complication prevention. Vaccines are available for some viruses and remain the main prevention strategy, coupled with vector control [104]. Several drugdeveloping strategies against FV have been discussed. For instance, the review of Boldescu et al. proposes that anti-flavivirus drug development should focus on targeting NS3 and NS5. They also mention an interest in broad-spectrum activity regarding the structural proximity of Flaviviridae [105].

Nowadays, little to no information is available on the anti-flavivirus activity of plantderived peptides, with few exceptions.

\subsubsection{Yellow Fever Virus (YFV)}

Yellow fever virus (YFV) is a member of the family Flaviviridae, genus Flavivirus. The YFV genome is a single-stranded positive-sense RNA genome coding for a polyprotein, which is processed into three structural proteins and seven non-structural proteins. The major component of the virion surface is the envelope (E) protein and membrane (M) protein. It is the primary immunogen and plays a central role in receptor binding and membrane fusion [106]. There are 70 serotypes of YFV, which are transmitted by mosquitos (Aedes and Haemogogus species) and ticks. 
Yellow fever is currently endemic in tropical regions of Africa and South America, where sporadic cases, limited outbreaks, or large epidemics are periodically detected on both continents [107].

Efficient vaccines (Stamaril, YF-VAX, 17D-YFV) with an attenuated virus are available, but epidemics continue to spread in new areas due to population movement.

The risk-versus-benefit of vaccinating at-risk immunocompromised persons (e.g., HIV-infected, rheumatoid arthritis patients under treatment with disease-modifying antirheumatic drugs, DMARD) against YFV poses numerous challenges, leading to the question of whether withholding YF vaccination for immunocompromised travelers is reasonable [108].

According to the PanAmerican Health Organization, a WHO subdivision, YFV infects 200,000 people each year, leading to 30,000 deaths, resulting in a mortality of $15 \%$ [107].

Monkeys are the main reservoir of the virus and mosquitos are the vectors. Humans (e.g., forest workers) can be infected through mosquito bites, which leads to sporadic cases.

Larger epidemics occur when a virus is introduced into an urban area with a high human and mosquito population density. Lack of vaccination or prior exposure to YFV could lead to the worst-case scenario for YFV epidemics. During the infection, prevention and treatment of dehydration, as well as prevention of kidney and liver failure, increase the survival rate [109].

According to Fiegueiredo et al., a steroidal saponin from Solanum sisylbriifolium (ethanolic extract) may have an inhibitory activity against DENV and YFV [110].

Two report studies dating from 2003 and 2009 show that essential oils from aromatic plants of San Luis, Argentina, along with citral, limonene and essential oils from Lippia citriodora and L. albahave present antiviral activity against YFV. No plant-derived peptides have been described yet as potential anti-YFV agents [111]. The question whether plantderived peptides can play a potential role as anti-YFV is still under investigation.

\subsubsection{Dengue Virus (DENV)}

DENV is an enveloped virus with a single positive-stranded RNA of the family Flaviviridae. The DENV genome codes for three structural proteins (capsid protein C, membrane protein $M$, envelope protein E) and seven nonstructural proteins (NS1, NS2a, NS2b, NS3, NS4a, NS4b, NS5) [112].

Each year, between 100 and 400 million humans are infected by this virus, transmitted by female mosquitoes of Aedes species (Ae. aegypti or Ae. albopictus) in countries with a subtropical and tropical climate. Four different viral serotypes exist and forms of infections can vary from subclinical to severe dengue with life-threatening situation. The disease is currently incurable and the incidence of novel infections has increased in recent years [113].

The sequence of the cyclotide kalata B1, known for its anti-HIV activity as described above, has been modified to present an anti-DENV activity. Called "kalata B1-inspired peptide", it inhibits dengue NS2B-NS3 protease, which leads to aborted viral replication [28].

Two peptides, called peptides 2 and 4, derived from the Asian medicinal plant Acacia catechu (Fabaceae-originally found in Asia) present an anti-DENV activity by targeting the early steps of the viral entry phase. The study of Panya et al. demonstrates that these two peptides at a concentration of $50 \mu \mathrm{M}$ stop more than $90 \%$ of DENV foci formation, defined as localized clusters of infected cells. Their $\mathrm{IC}_{50}$ value is $0.18 \mu \mathrm{g} / \mathrm{mL}$. According to the authors, $1.25 \mu \mathrm{g} / \mathrm{mL}$ of peptides results in a 100-fold virus production reduction without toxicity to cells [66].

Another study based on a synthetic bioactive peptide extracted from the same plant confirmed its efficiency against the four serotypes of DENV. Further investigations with this peptide, called Pep-RTYM, showed that it targets the early step of virus infection, similar to the kalata B1-inspired peptide. Incubation of Pep-RTYM with the virus before infection of the host cells results in more effective inhibition than incubation with the peptide during or after infection of the host cell with DENV. Binding assays led to the conclusion that 
PEP-RYTM binds viral particles. Moreover, it also inhibits the replication and production of novel viral particles in a dose-dependent manner [66].

Cystine knot $\alpha$-amylase inhibitors, also called alstotides, are cysteine- and prolinerich peptides derived from Amaranthaceae and Apocynaceae species. Alstonia scholaris contains the As1 peptide, which has been added to cells at the same time as the DENV serotype 2. The expression of nonstructural viral protein 3 (NS3) after 3 days of incubation with the peptide is reduced and the $\mathrm{EC}_{50}$ value is close to $90 \mu \mathrm{M}$ [67].

\subsubsection{Japan Encephalitis Virus (JEV)}

Japanese encephalitis virus (JEV) is a member of the flavivirus family. Its positivesense single-strand RNA genome codes for three structural proteins: Capsid (C), membrane $(\mathrm{prM} / \mathrm{M})$ and envelope protein (E), and seven non-structural (NS) proteins: NS1, NS2A, NS2B, NS3, NS4, NS4B, and NS5. The external envelope of the virus contains E and M proteins that play a role in host cell invasion. The virus contains also a nucleocapsid which is composed of multiple copies of the capsid protein, enclosing the nucleic acid [114].

JEV is the main cause for arbovirus encephalitis worldwide. It is an endemic virus widely distributed in Asia, including Japan, China, Taiwan, Korea, the Philippines, farEastern Russia, Southeast Asia, India, Papua New Guinea, and the Torres Strait of Australia. As in the majority of viral infections, there is no specific antiviral treatment for JEV infections; there is only supportive care and management of the clinical complications.

Only one vaccine has been authorized for JEV infection, based on inactivated viral particles. However, it remains expensive, and antibody protection is not conserved on a long term, requiring multiple administrations. Recombinant vaccines are currently being developed and are at the clinical trial stage [103].

A study conducted by Navyashree et al. aimed to evaluate the docking potential of phytoconstituents (i.e., perolyrine, 5,11 Dihydroindolol [3, 2- $\beta]$ carbazole, 1-methoxycarbonyl- $\beta$ carboline, 1-( $\beta$-carboline-1-yl)-3,4,5-trihydroxy-1-pentanone and (S)-1-(1'-hydroxyethyl)- $\beta$ carboline) of the Arisaema genus. The authors concluded that pyroline and 5,11-Dihydroindolo $[3,2-\beta]$ carbazole interact with viral proteins such as NS3 and NS5 helicase, presenting good pharmacokinetics and safety profiles. However, further analyses are needed to confirm the antiviral activity [115].

In vitro experiments showed that treatment of JEV with griffithsin (GRFT), a lectin isolated from the red marine alga Griffithsia sp., in BHK- 21 cells inhibited JEV with an $\mathrm{IC}_{50}$ of $20 \mathrm{nM}$. In vivo experiment showed that GRFT $(5 \mathrm{mg} / \mathrm{kg})$ administered intraperitoneally could prevent mortality in mice challenged intraperitoneally with a lethal dose of JEV. Further research is required to elucidate the mechanism by which GRFT exerts its anti-JEV activity. As in other viruses such as severe acute respiratory syndrome coronavirus (SARS$\mathrm{CoV}$ ) [32], and HIV-1 [87], it was found that GRFT binds to glycosylated viral proteins to inhibit infection [33].

\subsubsection{Tick-Borne Encephalitis Virus (TBEV)}

Among flaviviruses, tick-borne encephalitis virus (TBEV) contains a spherical, enveloped capsid. It has a long positive-strand RNA genome that encodes for ten main viral proteins. The three structural proteins (SP) consist of capsid protein (C), viral envelope (E) and membrane (M) proteins. The seven non-structural proteins (NS) (NS1, NS2A, NS2B, NS3,NS4A, NS4B and NS5) have a role in the replication machinery of the viral genome [116].

Tick-borne viruses regroup the TBE complex ( 8 viruses, including TBEV), which infect mammals, and the Tyuleniy group (3 viruses), which infects seabirds. Three subtypes of TBEV are known depending on their geographical origins (European, Siberian, and Far Eastern). Ticks from the Ixodes genus are the principal vector and reservoir of the virus. Person-to-person transmission has not been reported, but vertical transmission from infected mother to fetus has been described. Infection can also occur by drinking raw milk from infected goats, sheep, or cows. Between 10,000 to 15,000 cases of TBEV infection 
are reported in Asia and in Europe each year. The best prevention against TBEV remains vaccination [116].

\subsubsection{Zika Virus (ZIKV)}

ZIKA Virus (ZIKV) is one of the enveloped viruses. It is a positive-sense, singlestranded RNA virus, encoding three structural proteins: capsid (C); membrane (M); and envelope (E) and seven 7 nonstructural proteins (NS1, NS2A, NS2B, NS3, NS4A, NS4B, and NS5) that assist in replication of the genome and packaging of the virion [117].

In the period between 2007 and 2013, ZIKV revealed its epidemic potential with more than 20,000 infected people. There are no specific treatments nor a vaccine. Treatment is mostly symptomatic with acetaminophen and antihistaminic molecules $[117,118]$.

It has been reported that several promising plant-based products including peptides have shown activity against ZIKV, especially when NS2B and NS3 viral proteins are targeted, and could be used for drug design [104].

\subsubsection{Chikungunya Virus (CHIKV)}

Chikungunya virus (CHIKV) is an emerging mosquito-transmitted pathogen belonging to the Alphavirus genus of the Togaviridae family. Their structure consists of enveloped icosahedral capsids, which contain a single-stranded positive RNA, encoding five structural proteins (capsid [C], E3, E2, 6K/TF, and E1) responsible for the production of infectious virions; and four nonstructural proteins (nsP1, nsP2, nsP3 and nsP4) that are implicated in viral replication and transcription processes [119].

CHIKV was reported firstly in Tanzania in 1952 and emerged as an epidemic in 2005 in the French island of Réunion, then spread in different countries including Asia, Europe and Africa. This infectious disease causes high fever, headache, rashes, myalgia, arthralgia, and crippling arthritis that may persist for a long time. Other severe symptoms, including encephalitis, hemorrhagic disease, and mortality, have also been reported during recent epidemics [119]. Currently, there are no licensed vaccines or antivirals available against CHIKV infection [120].

Chitinase (chi)-like lectin, isolated from Tamarindus indica (TCLL), showed antiviral activity against CHIKV. Experimentation was performed using BHK-21 (cells derived from baby hamster kidney) and Vero cells. It was demonstrated that CHIKV viral RNA levels upon treatment with $100 \mu \mathrm{M}$ lectin were reduced to nearly 45\% [69].

\subsubsection{Hepatitis C Virus (HCV)}

Hepatitis $\mathrm{C}$ virus (HCV) is composed of an icosahedral enveloped capsid with a positive single-stranded RNA. It belongs to the Flaviviridae family, that contains viral envelope glycoproteins, E1 and E2, which are embedded in the lipid envelope and implicated in the invasion into the host cell [121]. HCV enters into hepatocytes and causes cell necrosis leading to a systematic viral infection that can be acute or chronic [122].

$\mathrm{HCV}$ infection is a public health problem with a global prevalence up to $2.8 \%$ of chronic infections [122]. According to the WHO, infection with HCV does not always require treatment, particularly in immunocompetent persons. However, HCV infection should be treated in all patients with chronic HCV infection over the age of 12 . Only pangenotypic direct-acting antiviral (DAAs) treatment remains effective, but it is expensive in many high- and upper-middle-income countries $[123,124]$. It was reported that GRFT lectin has the most potent anti-HCV activity with an $\mathrm{EC}_{50}$ value of $0.4 \mathrm{nM}$. GRFT showed low toxicity exhibiting a 50\% cytotoxic concentration $\left(\mathrm{CC}_{50}\right)$ equal to $34 \mathrm{mM}$ [34].

\subsection{Infectious Bronchitis Virus (IBV)}

IBV is a gammacoronavirus (RNA simple strand, positive sense, enveloped virus) that infects birds, mainly chickens. The IBV genome is very diverse in nature and numerous serotypes exist; this is probably due to the recombination between two or more strains during coinfection in chickens and to the low fidelity rate of the viral RNA-dependent 
RNA polymerase (RdRp). The disease, which is highly contagious, principally damages the upper respiratory system followed by the loss of ciliature activity due to viral fixation on sialylaminoglycan on the epithelium, leading to respiratory distress. The virus-damaged epithelium can thus enhance coinfection with bacteria. The kidneys and reproductive system can also be infected $[125,126]$.

The presence of different viral serotypes, which do not cross-react with IBV infectioninduced antibodies, leads to difficulties in controlling the spread of the viruses.

According to Jackwood (2012) and Bande (2017), at least 10 types of IBV are frequently isolated in the USA, with several variants for each type, which means the viruses continue changing and evolving. The same review mentions at least 8 different types for Europe, China, and 4 for Korea, Israel, and Japan, each, illustrating the great diversity of the virus [125,127].

According to Cavanagh, IBV is the main infectious disease with major economic loss in several countries due to the hundreds of IBV serotypes, differing mostly in one of the two viral spike surface glycoproteins (S1) structure by about 20-25\% [128].

Vaccination remains the main strategy against IBV, with several challenges due to the variants and the diversity of serotypes [129].

Some peptides from other origins have been reported to have an antiviral action [130]. One such example is knottins-antimicrobial peptides containing 3 disulfide bonds, with many members in plants, but also present in other eukaryotes. Alstotides are knottins from the blackboard tree Alstonia scholaris. Parthasarathy reported the anti-IBV activity of one alstotide, As1, which functions by blocking the spike protein and thus inhibiting the fusion of the virus with the host cell during the viral replication cycle. The same knottin may also interact with the IBV membrane (M) protein and consequently present a multitarget activity [68].

The examples of antiviral plant peptides remain few, but IBV is an epidemiological and economic threat to avian industries. Thus, IBV's molecular diversity and continuous tendency of emerging new variants, combined with its proximity to the human population, should encourage the research of plant-based strategies as plants remain an interesting source of bioactive molecules, including peptides.

\subsection{Foot and Mouth Disease Virus (FMDV) and Coxsackie Virus}

Foot and mouth disease virus (FMDV) has a capsid enclosing a positive singlestranded RNA. The FMDV genome encodes for four structural polypeptides (VP1 to VP4) and a nonstructural protein (NSP) that help the virus to evade the host immune mechanisms and cause an aggressive infection [131]. FMDV is a very contagious pathogen that affects a wide range of cloven-hoofed animals [132]. FMDV contains seven serotypes (types O, A, C, and Asia and the South African territories types 1, 2 and 3) [133]. Meliacine, a peptide which targets the replication cycle of HSV-1, was described as having an inhibitory effect on FMDV attachment to the cell surface. Meliacine inhibits FMDV virulence in BHK-21 monolayers in a dose-dependent manner, with an the $\mathrm{EC}_{50}$ of $0.5 \mathrm{mg} / \mathrm{mL}$ [50]. In addition, a lectin was purified from the rhizomes of Aspidistra elation Blume, named A. elatior lectin (AEL); it appears to have antiviral activity against Coxsackie Virus B4 with an $\mathrm{IC}_{50}$ of about $4 \mu \mathrm{g} / \mathrm{mL}[70]$.

\subsection{Ebola Virus}

Ebola virus disease (EVD) constitutes the family Filoviridae within the order Mononegavirales. It contains an RNA genome and seven viral proteins implicated in replication, transcription and viral assembly: NP, VP35, VP40, GP (glycoprotein), VP30, VP24, and an RNA-dependent RNA polymerase (L) [134].

EVD is a fatal syndrome in humans, with average case fatality rates of around $50 \%$. It causes gastrointestinal symptoms such as severe watery diarrhea, nausea, vomiting, abdominal pain and fever [135]. Currently, there is no licensed vaccine or treatment for EVD [136]. It has been previously reported that engineered banana lectin (BanLec) has an 
antiviral activity against viruses including Ebola virus. BanLec inhibited both entry and replication of Ebola virus in HEK293T /17 (human embryonic kidney) cell cultures, with $\mathrm{IC}_{50}$ values of about $1 \pm 6 \mu \mathrm{M}$ [71].

\subsection{Coronavirus}

The coronavirus belongs to the family Coronaviridae, order of Nidovirales and the suborder of Coronavirineae. It contains a positive-sense single-stranded RNA polymer surrounded by a protective capsid, which contains nucleocapsid (N). The coronavirus particle is surrounded by an outer membrane envelope made of lipids with viral proteins inserted, including the spike (S), membrane (M), and envelope (E) proteins [137].

The severe acute respiratory syndrome coronavirus (SARS-CoV) is a strain of coronavirus that causes severe respiratory syndromes [138]. This infection spread rapidly and results in the appearance of a pandemic as it was reported in the early months of 2020 . The WHO announced a novel SARS-CoV- 2 strain, named coronavirus disease 2019 (COVID19), which has developed into a global pandemic since March 2020 [139]. Moreover, 2012 SARS-CoV caused a pandemic named Middle East respiratory syndrome (MERS)-CoV, reported particularly in the Middle East region [140]. No specific effective treatment has been clinically developed. Several medical companies are working on antiviral drugs, but to date, only some vaccines are used as a preventive measure against the disease, while others are still being validated or tested [141]. Some studies evaluated the antiviral effect of griffithsin (GRFT), a lectin isolated from the red marine alga Griffithsia sp., against SARS$\mathrm{CoV}$ and MERS-CoV infections [19,32,35]. The antiviral study of GRFT against SARS-CoV (Urbani strain, MA15) showed that GRFT lectin potently inhibits the cytopathic effect of SARS-CoV in Vero 76 cells; GRFT reduced the percentage of cells killed by SARS-CoV (Urbani, MA15) in a concentration-dependent manner (EC $5048 \mathrm{nM}$ ) [32].

The antiviral effect of GRFT against MERS-CoV infection demonstrated that GRFT inhibits MERS-CoV spike protein function (mediates binding to the host cell surface) during the entry into host cells at $2 \mathrm{mg} / \mathrm{mL}$. Consequently, GRFT could be a potent inhibitor of MERS-CoV infection [35].

Future research efforts focused on the GRFT lectin, and other plant-derived antimicrobial peptides, might provide effective therapeutic options for the treatment of COVID-19 and other viral infections causing debilitating diseases and global pandemics.

\section{Conclusions}

Interest in peptides has been increasing for several years now, in particular for their therapeutic potential in many fields such as viral infections and microbial infections. They have numerous advantages: a broad range of activities, low side effects in the host due to high selectivity, specificity, biocompatibility, ability to penetrate cells, and low toxicity, antigenicity and immunogenicity. However, very scarce information is available on plant peptides with antiviral activity in the existing scientific literature and the current state of knowledge is quite limited on this topic. This is contrasting with other plant-derived molecules (i.e., terpenoids, saponins, or glycans), which have been extensively explored for their anti-infectious properties. Finally, even if plant peptides have not revealed their full potential yet, they remain interesting to explore in the context of emerging and reemerging infectious diseases. The traditional use of plant-derived drugs remains the principal source of bioactive molecules worldwide. This review underlines the need for further investigations on the mechanisms of action of plant-derived peptides. There is also a need for new formulation strategies to enable the development of new drug candidates and peptide-based antiviral therapies.

Author Contributions: The manuscript was written through contributions of all authors, as it follows: conceptualization: M.V. Authors of chapters: N.M., Y.K., Q.A. and M.V. Writing-review and editing: M.V., N.M., Y.K., Q.A. and M.D. Supervision: M.V. Project administration: M.V. Funding acquisition: M.V., on behalf of the French team of OEMONOM. All authors have read and agreed to the published version of the manuscript. 
Funding: This open-access review paper was supported by the Erasmus+ Programme of the European Union, Key Action 2: Strategic Partnerships, Project No. 2020-1-CZ01-KA203-078218. The authors also acknowledge the support of the EFSA-CDN project (CZ.02.1.01/0.0/0.0/16_019/0000841) co-funded by the ERDF and research funding to MD supported by a grant from Science Foundation Ireland (SFI, grant 12/RC/2275_P2).

Institutional Review Board Statement: Not applicable.

Informed Consent Statement: Not applicable.

Data Availability Statement: Data sharing not applicable.

Acknowledgments: Open Access Educational Materials on Naturally Occurring Molecules (https: // portal.faf.cuni.cz/OEMONOM/EN/ (accessed on 2 August 2021)). The authors would like to express their gratitude to Manon Delorme for the careful proofreading of the manuscript, and for useful discussion and comments on the work.

Conflicts of Interest: The authors declare no conflict of interest.

\section{References}

1. Deeter, R.G.; Khanderia, U. Recent Advances in Antiviral Therapy. Clin. Pharm. 1986, 5, 961-976. [PubMed]

2. Whitley, R.; Alford, C.; Hess, F.; Buchanan, R. Vidarabine: A Preliminary Review of Its Pharmacological Properties and Therapeutic Use. Drugs 1980, 20, 267-282. [CrossRef] [PubMed]

3. Thompson, C.; Whitley, R. Neonatal Herpes Simplex Virus Infections: Where Are We Now? Adv. Exp. Med. Biol. 2011, 697, 221-230. [CrossRef] [PubMed]

4. Darby, G. Acyclovir-and Beyond. J. Int. Med. Res. 1994, 22 (Suppl. 1), 33A-42A. [PubMed]

5. McCormick, J.B.; King, I.J.; Webb, P.A.; Scribner, C.L.; Craven, R.B.; Johnson, K.M.; Elliott, L.H.; Belmont-Williams, R. Lassa Fever. Effective Therapy with Ribavirin. N. Engl. J. Med. 1986, 314, 20-26. [CrossRef] [PubMed]

6. Li, D.K.; Chung, R.T. Overview of Direct-Acting Antiviral Drugs and Drug Resistance of Hepatitis C Virus. Methods Mol. Biol. 2019, 1911, 3-32. [CrossRef] [PubMed]

7. Krishna, B.A.; Wills, M.R.; Sinclair, J.H. Advances in the Treatment of Cytomegalovirus. Br. Med. Bull. 2019, 131, 5-17. [CrossRef]

8. Chen, S.-J.; Wang, S.-C.; Chen, Y.-C. Antiviral Agents as Therapeutic Strategies Against Cytomegalovirus Infections. Viruses 2020, 12, 21. [CrossRef] [PubMed]

9. Han, J.; Perez, J.; Schafer, A.; Cheng, H.; Peet, N.; Rong, L.; Manicassamy, B. Influenza Virus: Small Molecule Therapeutics and Mechanisms of Antiviral Resistance. Curr. Med. Chem. 2018, 25, 5115-5127. [CrossRef]

10. Weber, I.T.; Harrison, R.W. Tackling the Problem of HIV Drug Resistance. Postepy Biochem. 2016, 62, 273-279. [PubMed]

11. Pawlotsky, J.-M. Hepatitis C Virus Resistance to Direct-Acting Antiviral Drugs in Interferon-Free Regimens. Gastroenterology 2016, 151, 70-86. [CrossRef] [PubMed]

12. Bagaglio, S.; Uberti-Foppa, C.; Morsica, G. Resistance Mechanisms in Hepatitis C Virus: Implications for Direct-Acting Antiviral Use. Drugs 2017, 77, 1043-1055. [CrossRef] [PubMed]

13. Vilas Boas, L.C.P.; Campos, M.L.; Berlanda, R.L.A.; de Carvalho Neves, N.; Franco, O.L. Antiviral Peptides as Promising Therapeutic Drugs. Cell Mol. Life Sci. 2019, 76, 3525-3542. [CrossRef] [PubMed]

14. Weidmann, J.; Craik, D.J. Discovery, Structure, Function, and Applications of Cyclotides: Circular Proteins from Plants. J. Exp. Bot. 2016, 67, 4801-4812. [CrossRef]

15. Craik, D.J.; Du, J. Cyclotides as Drug Design Scaffolds. Curr. Opin. Chem. Biol. 2017, 38, 8-16. [CrossRef] [PubMed]

16. Wang, G. Natural Antimicrobial Peptides as Promising Anti-HIV Candidates. Curr. Top. Pept. Protein Res. 2012, 13, 93-110.

17. Ishaq, N.; Bilal, M.; Iqbal, H.M.N. Medicinal Potentialities of Plant Defensins: A Review with Applied Perspectives. Medicines 2019, 6, 29. [CrossRef] [PubMed]

18. Akkouh, O.; Ng, T.B.; Singh, S.S.; Yin, C.; Dan, X.; Chan, Y.S.; Pan, W.; Cheung, R.C.F. Lectins with Anti-HIV Activity: A Review. Molecules 2015, 20, 648-668. [CrossRef] [PubMed]

19. Lee, C. Griffithsin, a Highly Potent Broad-Spectrum Antiviral Lectin from Red Algae: From Discovery to Clinical Application. Marine Drugs 2019, 17, 567. [CrossRef] [PubMed]

20. Swanson, M.D.; Winter, H.C.; Goldstein, I.J.; Markovitz, D.M. A Lectin Isolated from Bananas Is a Potent Inhibitor of HIV Replication. J. Biol. Chem. 2010, 285, 8646-8655. [CrossRef] [PubMed]

21. Corbeau, P.; Haran, M.; Binz, H.; Devaux, C. Jacalin, a Lectin with Anti-HIV-1 Properties, and HIV-1 Gp120 Envelope Protein Interact with Distinct Regions of the CD4 Molecule. Mol. Immunol. 1994, 31, 569-575. [CrossRef]

22. Witvrouw, M.; Fikkert, V.; Hantson, A.; Pannecouque, C.; O’keefe, B.R.; McMahon, J.; Stamatatos, L.; de Clercq, E.; Bolmstedt, A. Resistance of Human Immunodeficiency Virus Type 1 to the High-Mannose Binding Agents Cyanovirin N and Concanavalin A. J. Virol. 2005, 79, 7777-7784. [CrossRef] [PubMed]

23. Xu, H.; Li, C.; He, X.; Niu, K.; Peng, H.; Li, W.; Zhou, C.; Bao, J. Molecular Modeling, Docking and Dynamics Simulations of GNA-Related Lectins for Potential Prevention of Influenza Virus (H1N1). J. Mol. Model. 2012, 18, 27-37. [CrossRef] [PubMed] 
24. Charan, R.D.; Munro, M.H.; O’Keefe, B.R.; Sowder, R.; McKee, T.C.; Currens, M.J.; Pannell, L.K.; Boyd, M.R. Isolation and Characterization of Myrianthus Holstii Lectin, a Potent HIV-1 Inhibitory Protein from the Plant Myrianthus Holstii(1). J. Nat. Prod. 2000, 63, 1170-1174. [CrossRef] [PubMed]

25. López, S.; Armand-Ugon, M.; Bastida, J.; Viladomat, F.; Esté, J.A.; Stewart, D.; Codina, C. Anti-Human Immunodeficiency Virus Type 1 (HIV-1) Activity of Lectins from Narcissus Species. Planta Med. 2003, 69, 109-112. [CrossRef]

26. Ding, J.; Bao, J.; Zhu, D.; Zhang, Y.; Wang, D.-C. Crystal Structures of a Novel Anti-HIV Mannose-Binding Lectin from Polygonatum Cyrtonema Hua with Unique Ligand-Binding Property and Super-Structure. J. Struct. Biol. 2010, 171, 309-317. [CrossRef]

27. Sato, Y.; Hirayama, M.; Morimoto, K.; Yamamoto, N.; Okuyama, S.; Hori, K. High Mannose-Binding Lectin with Preference for the Cluster of Alpha1-2-Mannose from the Green Alga Boodlea Coacta Is a Potent Entry Inhibitor of HIV-1 and Influenza Viruses. J. Biol. Chem. 2011, 286, 19446-19458. [CrossRef]

28. Gao, Y.; Cui, T.; Lam, Y. Synthesis and Disulfide Bond Connectivity-Activity Studies of a Kalata B1-Inspired Cyclopeptide against Dengue NS2B-NS3 Protease. Bioorg. Med. Chem. 2010, 18, 1331-1336. [CrossRef]

29. Derby, N.; Lal, M.; Aravantinou, M.; Kizima, L.; Barnable, P.; Rodriguez, A.; Lai, M.; Wesenberg, A.; Ugaonkar, S.; Levendosky, K.; et al. Griffithsin Carrageenan Fast Dissolving Inserts Prevent SHIV HSV-2 and HPV Infections in Vivo. Nat. Commun. 2018, 9 , 3881. [CrossRef] [PubMed]

30. Levendosky, K.; Mizenina, O.; Martinelli, E.; Jean-Pierre, N.; Kizima, L.; Rodriguez, A.; Kleinbeck, K.; Bonnaire, T.; Robbiani, M.; Zydowsky, T.M.; et al. Griffithsin and Carrageenan Combination To Target Herpes Simplex Virus 2 and Human Papillomavirus. Antimicrob. Agents Chemother. 2015, 59, 7290-7298. [CrossRef] [PubMed]

31. Mori, T.; O'Keefe, B.R.; Sowder, R.C.; Bringans, S.; Gardella, R.; Berg, S.; Cochran, P.; Turpin, J.A.; Buckheit, R.W.; McMahon, J.B.; et al. Isolation and Characterization of Griffithsin, a Novel HIV-Inactivating Protein, from the Red Alga Griffithsia Sp. J. Biol. Chem. 2005, 280, 9345-9353. [CrossRef] [PubMed]

32. O'Keefe, B.R.; Giomarelli, B.; Barnard, D.L.; Shenoy, S.R.; Chan, P.K.S.; McMahon, J.B.; Palmer, K.E.; Barnett, B.W.; Meyerholz, D.K.; Wohlford-Lenane, C.L.; et al. Broad-Spectrum In Vitro Activity and In Vivo Efficacy of the Antiviral Protein Griffithsin against Emerging Viruses of the Family Coronaviridae. J. Virol. 2010, 84, 2511-2521. [CrossRef]

33. Ishag, H.Z.A.; Li, C.; Wang, F.; Mao, X. Griffithsin Binds to the Glycosylated Proteins (E and PrM) of Japanese Encephalitis Virus and Inhibit Its Infection. Virus Res. 2016, 215, 50-54. [CrossRef]

34. Takebe, Y.; Saucedo, C.J.; Lund, G.; Uenishi, R.; Hase, S.; Tsuchiura, T.; Kneteman, N.; Ramessar, K.; Tyrrell, D.L.J.; Shirakura, M.; et al. Antiviral Lectins from Red and Blue-Green Algae Show Potent in Vitro and in Vivo Activity against Hepatitis C Virus. PLoS ONE 2013, 8, e64449. [CrossRef] [PubMed]

35. Millet, J.K.; Séron, K.; Labitt, R.N.; Danneels, A.; Palmer, K.E.; Whittaker, G.R.; Dubuisson, J.; Belouzard, S. Middle East Respiratory Syndrome Coronavirus Infection Is Inhibited by Griffithsin. Antiviral Res. 2016, 133, 1-8. [CrossRef] [PubMed]

36. Wong, J.H.; Ng, T.B. Limenin, a Defensin-like Peptide with Multiple Exploitable Activities from Shelf Beans. J. Pept. Sci. 2006, 12, 341-346. [CrossRef] [PubMed]

37. Herpes Simplex Virus. Available online: https://www.who.int/news-room/fact-sheets/detail/herpes-simplex-virus (accessed on 1 May 2021).

38. Kukhanova, M.K.; Korovina, A.N.; Kochetkov, S.N. Human Herpes Simplex Virus: Life Cycle and Development of Inhibitors. Biochem. Moscow 2014, 79, 1635-1652. [CrossRef] [PubMed]

39. Farr Zuend, C.; Nomellini, J.F.; Smit, J.; Horwitz, M.S. Generation of a Dual-Target, Safe, Inexpensive Microbicide That Protects Against HIV-1 and HSV-2 Disease. Sci. Rep. 2018, 8. [CrossRef] [PubMed]

40. Adebo, O.A. African Sorghum-Based Fermented Foods: Past, Current and Future Prospects. Nutrients 2020, 12, 1111. [CrossRef] [PubMed]

41. Salas, C.E.; Badillo-Corona, J.A.; Ramírez-Sotelo, G.; Oliver-Salvador, C. Biologically Active and Antimicrobial Peptides from Plants. Biomed. Res. Int. 2015, 2015, 102129. [CrossRef] [PubMed]

42. Camargo Filho, I.; Cortez, D.A.G.; Ueda-Nakamura, T.; Nakamura, C.V.; Dias Filho, B.P. Antiviral Activity and Mode of Action of a Peptide Isolated from Sorghum Bicolor. Phytomedicine 2008, 15, 202-208. [CrossRef] [PubMed]

43. Dadé, M.; Zeinsteger, P.; Bozzolo, F.; Mestorino, N. Repellent and Lethal Activities of Extracts From Fruits of Chinaberry (Melia Azedarach L., Meliaceae) Against Triatoma Infestans. Front. Vet. Sci. 2018, 5. [CrossRef] [PubMed]

44. Alché, L.E.; Barquero, A.A.; Sanjuan, N.A.; Coto, C.E. An Antiviral Principle Present in a Purified Fraction from Melia Azedarach L. Leaf Aqueous Extract Restrains Herpes Simplex Virus Type 1 Propagation. Phytother. Res. 2002, 16, 348-352. [CrossRef]

45. Alché, L.E.; Berra, A.; Veloso, M.J.; Coto, C.E. Treatment with Meliacine, a Plant Derived Antiviral, Prevents the Development of Herpetic Stromal Keratitis in Mice. J. Med. Virol. 2000, 61, 474-480. [CrossRef]

46. Barquero, A.A.; Alché, L.E.; Coto, C.E. Antiviral Activity of Meliacine on the Replication of a Thymidine Kinase-Deficient Mutant of Herpes Simplex Virus Type 1 Alone and in Combination with Acyclovir. Int. J. Antimicrob. Agents 1997, 9, 49-55. [CrossRef]

47. Ali, S.I.; Sheikh, W.M.; Rather, M.A.; Venkatesalu, V.; Muzamil Bashir, S.; Nabi, S.U. Medicinal Plants: Treasure for Antiviral Drug Discovery. Phytother. Res. 2021. [CrossRef] [PubMed]

48. Petrera, E.; Coto, C.E. Effect of Meliacine, a Plant Derived Antiviral, on Tumor Necrosis Factor Alpha. Fitoterapia 2003, 74, 77-83. [CrossRef] 
49. Castilla, V.; Barquero, A.A.; Mersich, S.E.; Coto, C.E. In Vitro Anti-Junin Virus Activity of a Peptide Isolated from Melia Azedarach L. Leaves. Int. J. Antimicrob. Agents 1998, 10, 67-75. [CrossRef]

50. Wachsman, M.B.; Castilla, V.; Coto, C.E. Inhibition of Foot and Mouth Disease Virus (FMDV) Uncoating by a Plant-Derived Peptide Isolated from Melia Azedarach L. Leaves. Arch. Virol. 1998, 143, 581-590. [CrossRef]

51. Henriques, S.T.; Huang, Y.-H.; Rosengren, K.J.; Franquelim, H.G.; Carvalho, F.A.; Johnson, A.; Sonza, S.; Tachedjian, G.; Castanho, M.A.R.B.; Daly, N.L.; et al. Decoding the Membrane Activity of the Cyclotide Kalata B1. J. Biol. Chem. 2011, 286, 24231-24241. [CrossRef] [PubMed]

52. Daly, N.L.; Clark, R.J.; Plan, M.R.; Craik, D.J. Kalata B8, a Novel Antiviral Circular Protein, Exhibits Conformational Flexibility in the Cystine Knot Motif. Biochem. J. 2006, 393, 619-626. [CrossRef] [PubMed]

53. Wong, J.H.; Ng, T.B. Vulgarinin, a Broad-Spectrum Antifungal Peptide from Haricot Beans (Phaseolus Vulgaris). Int. J. Biochem. Cell. Biol. 2005, 37, 1626-1632. [CrossRef] [PubMed]

54. Wong, J.H.; Ng, T.B. Lunatusin, a Trypsin-Stable Antimicrobial Peptide from Lima Beans (Phaseolus Lunatus L.). Peptides 2005, 26, 2086-2092. [CrossRef]

55. Ye, X.Y.; Ng, T.B.; Rao, P.F. Cicerin and Arietin, Novel Chickpea Peptides with Different Antifungal Potencies. Peptides 2002, 23, 817-822. [CrossRef]

56. Ye, X.Y.; Ng, T.B. Isolation of a New Cyclophilin-like Protein from Chickpeas with Mitogenic, Antifungal and Anti-HIV-1 Reverse Transcriptase Activities. Life Sci. 2002, 70, 1129-1138. [CrossRef]

57. Wang, H.X.; Ng, T.B. An Antifungal Peptide from Baby Lima Bean. Appl. Microbiol. Biotechnol. 2006, 73, 576-581. [CrossRef]

58. Wang, H.X.; Ng, T.B. An Antifungal Peptide from the Coconut. Peptides 2005, 26, 2392-2396. [CrossRef] [PubMed]

59. Gustafson, K.R.; Sowder, R.C.; Henderson, L.E.; Parsons, I.C.; Kashman, Y.; Cardellina, J.H.; McMahon, J.B.; Buckheit, R.W.; Pannell, L.K.; Boyd, M.R. Circulins A and B. Novel Human Immunodeficiency Virus (HIV)-Inhibitory Macrocyclic Peptides from the Tropical Tree Chassalia Parvifolia. J. Am. Chem. Soc. 1994, 116, 9337-9338. [CrossRef]

60. Lin, P.; Ng, T.B. Preparation and Biological Properties of a Melibiose Binding Lectin from Bauhinia Variegata Seeds. J. Agric. Food Chem. 2008, 56, 10481-10486. [CrossRef] [PubMed]

61. Gordts, S.C.; Renders, M.; Férir, G.; Huskens, D.; Van Damme, E.J.M.; Peumans, W.; Balzarini, J.; Schols, D. NICTABA and UDA, Two GlcNAc-Binding Lectins with Unique Antiviral Activity Profiles. J. Antimicrob. Chemother. 2015, 70, 1674-1685. [CrossRef]

62. Liu, M.-Z.; Yang, Y.; Zhang, S.-X.; Tang, L.; Wang, H.-M.; Chen, C.-J.; Shen, Z.-F.; Cheng, K.-D.; Kong, J.-Q.; Wang, W. A cyclotide against influenza A H1N1 virus from Viola yedoensis. Yao Xue Xue Bao Acta Pharm. Sin. 2014, 49, 905-912.

63. Maximiano, M.R.; Franco, O.L. Biotechnological Applications of Versatile Plant Lipid Transfer Proteins (LTPs). Peptides 2021, 140, 170531. [CrossRef] [PubMed]

64. Ooi, L.S.M.; Tian, L.; Su, M.; Ho, W.-S.; Sun, S.S.M.; Chung, H.-Y.; Wong, H.N.C.; Ooi, V.E.C. Isolation, Characterization, Molecular Cloning and Modeling of a New Lipid Transfer Protein with Antiviral and Antiproliferative Activities from Narcissus Tazetta. Peptides 2008, 29, 2101-2109. [CrossRef] [PubMed]

65. Ooi, L.S.M.; Ho, W.-S.; Ngai, K.L.K.; Tian, L.; Chan, P.K.S.; Sun, S.S.M.; Ooi, V.E.C. Narcissus Tazetta Lectin Shows Strong Inhibitory Effects against Respiratory Syncytial Virus, Influenza A (H1N1, H3N2, H5N1) and B Viruses. J. Biosci. 2010, 35, 95-103. [CrossRef] [PubMed]

66. Panya, A.; Yongpitakwattana, P.; Budchart, P.; Sawasdee, N.; Krobthong, S.; Paemanee, A.; Roytrakul, S.; Rattanabunyong, S.; Choowongkomon, K.; Yenchitsomanus, P.-T. Novel Bioactive Peptides Demonstrating Anti-Dengue Virus Activity Isolated from the Asian Medicinal Plant Acacia Catechu. Chem. Biol. Drug Des. 2019, 93, 100-109. [CrossRef] [PubMed]

67. Nguyen, P.Q.T.; Ooi, J.S.G.; Nguyen, N.T.K.; Wang, S.; Huang, M.; Liu, D.X.; Tam, J.P. Antiviral Cystine Knot $\alpha$-Amylase Inhibitors from Alstonia Scholaris. J. Biol. Chem. 2015, 290, 31138-31150. [CrossRef] [PubMed]

68. Parthasarathy, A.; Borrego, E.J.; Savka, M.A.; Dobson, R.C.J.; Hudson, A.O. Amino Acid-Derived Defense Metabolites from Plants: A Potential Source to Facilitate Novel Antimicrobial Development. J. Biol. Chem. 2021, 100438. [CrossRef] [PubMed]

69. Kaur, R.; Mudgal, R.; Jose, J.; Tomar, S. Glycan-Dependent Chikungunya Viral Infection Divulged by Antiviral Activity of NAG Specific Chi-like Lectin. Virology 2019, 526, 91-98. [CrossRef]

70. Xu, X.-C.; Zhang, Z.-W.; Chen, Y.-E.; Yuan, M.; Yuan, S.; Bao, J.-K. Antiviral and Antitumor Activities of the Lectin Extracted from Aspidistra Elatior. Zeitschrift Naturforschung C 2015, 70, 7-13. [CrossRef]

71. Covés-Datson, E.M.; Dyall, J.; DeWald, L.E.; King, S.R.; Dube, D.; Legendre, M.; Nelson, E.; Drews, K.C.; Gross, R.; Gerhardt, D.M.; et al. Inhibition of Ebola Virus by a Molecularly Engineered Banana Lectin. PLoS Negl. Trop. Dis. 2019, 13, e0007595. [CrossRef] [PubMed]

72. De Sanjosé, S.; Diaz, M.; Castellsagué, X.; Clifford, G.; Bruni, L.; Muñoz, N.; Bosch, F.X. Worldwide Prevalence and Genotype Distribution of Cervical Human Papillomavirus DNA in Women with Normal Cytology: A Meta-Analysis. Lancet Infect. Dis. 2007, 7, 453-459. [CrossRef]

73. Kombe Kombe, A.J.; Li, B.; Zahid, A.; Mengist, H.M.; Bounda, G.-A.; Zhou, Y.; Jin, T. Epidemiology and Burden of Human Papillomavirus and Related Diseases, Molecular Pathogenesis, and Vaccine Evaluation. Front. Public Health 2020, $8,552028$. [CrossRef]

74. Araújo, M.G.; Magalhães, G.M.; Garcia, L.C.; Vieira, É.C.; Carvalho-Leite, M.D.L.R.D.; Guedes, A.C.M. Update on Human Papillomavirus-Part II: Complementary Diagnosis, Treatment and Prophylaxis. An. Bras. Dermatol. 2021, 96, 125-138. [CrossRef] 
75. Vanangamudi, M.; Nair, P.C.; Engels, S.E.M.; Palaniappan, S.; Namasivayam, V. Structural Insights to Human Immunodeficiency Virus (HIV-1) Targets and Their Inhibition. Adv. Exp. Med. Biol. 2021, 1322, 63-95. [CrossRef] [PubMed]

76. UNAIDS. Global HIV \& AIDS Statistics-Fact Sheet. Available online: https://www.unaids.org/en/resources/fact-sheet (accessed on 11 June 2021).

77. Maeda, K.; Das, D.; Kobayakawa, T.; Tamamura, H.; Takeuchi, H. Discovery and Development of Anti-HIV Therapeutic Agents: Progress Towards Improved HIV Medication. Curr. Top. Med. Chem. 2019, 19, 1621-1649. [CrossRef] [PubMed]

78. Grover, T.; Mishra, R.; Gulati, P.; Mohanty, A. An Insight into Biological Activities of Native Cyclotides for Potential Applications in Agriculture and Pharmaceutics. Peptides 2021, 135, 170430. [CrossRef] [PubMed]

79. Ireland, D.C.; Wang, C.K.L.; Gustafson, K.R.; Craik, D.J. Cyclotides as Natural Anti-HIV Agents. Biopolymers 2008, 90, 51-60. [CrossRef] [PubMed]

80. Henriques, S.T.; Craik, D.J. Cyclotides as Templates in Drug Design. Drug Discov. Today 2010, 15, 57-64. [CrossRef]

81. Ngai, P.H.K.; Ng, T.B. Phaseococcin, an Antifungal Protein with Antiproliferative and Anti-HIV-1 Reverse Transcriptase Activities from Small Scarlet Runner Beans. Biochem. Cell Biol. 2005, 83, 212-220. [CrossRef] [PubMed]

82. Lin, P.; Xia, L.; Wong, J.H.; Ng, T.B.; Ye, X.; Wang, S.; Shi, X. Lipid Transfer Proteins from Brassica Campestris and Mung Bean Surpass Mung Bean Chitinase in Exploitability. J. Pept. Sci. 2007, 13, 642-648. [CrossRef]

83. Wong, J.H.; Ng, T.B. Sesquin, a Potent Defensin-like Antimicrobial Peptide from Ground Beans with Inhibitory Activities toward Tumor Cells and HIV-1 Reverse Transcriptase. Peptides 2005, 26, 1120-1126. [CrossRef]

84. Lin, P.; Wong, J.H.; Ng, T.B. A Defensin with Highly Potent Antipathogenic Activities from the Seeds of Purple Pole Bean. Biosci. Rep. 2009, 30, 101-109. [CrossRef] [PubMed]

85. Wong, J.H.; Ng, T.B. Gymnin, a Potent Defensin-like Antifungal Peptide from the Yunnan Bean (Gymnocladus Chinensis Baill). Peptides 2003, 24, 963-968. [CrossRef]

86. Hansen, J.E.; Nielsen, C.M.; Nielsen, C.; Heegaard, P.; Mathiesen, L.R.; Nielsen, J.O. Correlation between Carbohydrate Structures on the Envelope Glycoprotein Gp120 of HIV-1 and HIV-2 and Syncytium Inhibition with Lectins. AIDS 1989, 3, 635-641. [CrossRef]

87. Hu, B.; Du, T.; Li, C.; Luo, S.; Liu, Y.; Huang, X.; Hu, Q. Sensitivity of Transmitted and Founder Human Immunodeficiency Virus Type 1 Envelopes to Carbohydrate-Binding Agents Griffithsin, Cyanovirin-N and Galanthus Nivalis Agglutinin. J. Gen. Virol. 2015, 96, 3660-3666. [CrossRef]

88. Russell, C.J. Hemagglutinin Stability and Its Impact on Influenza A Virus Infectivity, Pathogenicity, and Transmissibility in Avians, Mice, Swine, Seals, Ferrets, and Humans. Viruses 2021, 13, 746. [CrossRef] [PubMed]

89. WHO. Pandemic (H1N1) 2009. Available online: https://www.euro.who.int/en/health-topics/communicable-diseases/ influenza/pandemic-influenza/past-pandemics/pandemic-h1n1-2009 (accessed on 25 June 2021).

90. Al Khatib, H.A.; Al Thani, A.A.; Gallouzi, I.; Yassine, H.M. Epidemiological and Genetic Characterization of PH1N1 and H3N2 Influenza Viruses Circulated in MENA Region during 2009-2017. BMC Infect. Dis. 2019, 19, 314. [CrossRef] [PubMed]

91. Lampejo, T. Influenza and Antiviral Resistance: An Overview. Eur J. Clin. Microbiol. Infect. Dis. 2020, 39, 1201-1208. [CrossRef]

92. Grant, A.; Seregin, A.; Huang, C.; Kolokoltsova, O.; Brasier, A.; Peters, C.; Paessler, S. Junín Virus Pathogenesis and Virus Replication. Viruses 2012, 4, 2317-2339. [CrossRef] [PubMed]

93. Cao, D.; Gao, Y.; Liang, B. Structural Insights into the Respiratory Syncytial Virus RNA Synthesis Complexes. Viruses 2021, 13, 834. [CrossRef]

94. Jorquera, P.A.; Tripp, R.A. Respiratory Syncytial Virus: Prospects for New and Emerging Therapeutics. Expert Rev. Respir. Med. 2017, 11, 609-615. [CrossRef]

95. Domachowske, J.B.; Anderson, E.J.; Goldstein, M. The Future of Respiratory Syncytial Virus Disease Prevention and Treatment. Infect. Dis. Ther. 2021, 10, 47-60. [CrossRef] [PubMed]

96. RSV Vaccine Research and Development Technology Roadmap. Available online: https://www.who.int/publications-detailredirect/WHO-IVB-17.12 (accessed on 25 June 2021).

97. Goldstein, E.; Nguyen, H.H.; Liu, P.; Viboud, C.; Steiner, C.A.; Worby, C.J.; Lipsitch, M. On the Relative Role of Different Age Groups During Epidemics Associated With Respiratory Syncytial Virus. J. Infect. Dis. 2018, 217, 238-244. [CrossRef]

98. Simoes, E.A.; Carbonell-Estrany, X. Impact of Severe Disease Caused by Respiratory Syncytial Virus in Children Living in Developed Countries. Pediatr. Infect. Dis. J. 2003, 22, S13-S18; discussion S18-S20. [CrossRef]

99. Fergie, J.; Goldstein, M.; Krilov, L.R.; Wade, S.W.; Kong, A.M.; Brannman, L. Update on Respiratory Syncytial Virus Hospitalizations among U.S. Preterm and Term Infants before and after the 2014 American Academy of Pediatrics Policy on Immunoprophylaxis: 2011-2017. Hum. Vaccin. Immunother. 2021, 17, 1536-1545. [CrossRef] [PubMed]

100. DeVincenzo, J.; Tait, D.; Efthimiou, J.; Mori, J.; Kim, Y.-I.; Thomas, E.; Wilson, L.; Harland, R.; Mathews, N.; Cockerill, S.; et al. A Randomized, Placebo-Controlled, Respiratory Syncytial Virus Human Challenge Study of the Antiviral Efficacy, Safety, and Pharmacokinetics of RV521, an Inhibitor of the RSV-F Protein. Antimicrob. Agents Chemother. 2020, 64. [CrossRef] [PubMed]

101. Ark Biosciences Inc. A Randomised, Double-Blind., Placebo-Controlled Study to Evaluate the Efficacy, Safety and Tolerability of Orally Administered AK0529 in Adults With Respiratory Syncytial Virus Infection; Ark Biosciences Inc.: Shanghai, China, 2019.

102. RSV Vaccine and MAb Snapshot. Available online: https://www.path.org/resources/rsv-vaccine-and-mab-snapshot/ (accessed on 16 June 2021). 
103. Contigiani, M.S.; Diaz, L.A.; Spinsanti, L. Flavivirus. In Arthropod Borne Diseases; Marcondes, C.B., Ed.; Springer International Publishing: Cham, Switzerland, 2017; pp. 73-88, ISBN 978-3-319-13884-8.

104. Rodriguez, A.K.; Muñoz, A.L.; Segura, N.A.; Rangel, H.R.; Bello, F. Molecular Characteristics and Replication Mechanism of Dengue, Zika and Chikungunya Arboviruses, and Their Treatments with Natural Extracts from Plants: An Updated Review. EXCLI J. 2019, 18, 988-1006. [CrossRef] [PubMed]

105. Boldescu, V.; Behnam, M.A.M.; Vasilakis, N.; Klein, C.D. Broad-Spectrum Agents for Flaviviral Infections: Dengue, Zika and Beyond. Nat. Rev. Drug Discov. 2017, 16, 565-586. [CrossRef] [PubMed]

106. Davis, E.H.; Barrett, A.D.T. Structure-Function of the Yellow Fever Virus Envelope Protein: Analysis of Antibody Epitopes. Viral Immunol. 2020, 33, 12-21. [CrossRef] [PubMed]

107. Yellow Fever-PAHO/WHOIPan American Health Organization. Available online: https://www.paho.org/en/topics/yellowfever (accessed on 16 June 2021).

108. Chen, L.H.; Wilson, M.E. Yellow Fever Control: Current Epidemiology and Vaccination Strategies. Trop. Dis. Travel Med. Vaccines 2020, 6, 1. [CrossRef] [PubMed]

109. Vasconcelos, P.F.C. Yellow Fever. In Arthropod Borne Diseases; Marcondes, C.B., Ed.; Springer International Publishing: Cham, Switzerland, 2017; pp. 101-113, ISBN 978-3-319-13884-8.

110. Figueiredo, G.G.; Coronel, O.A.; Trabuco, A.C.; Bazán, D.E.; Russo, R.R.; Alvarenga, N.L.; Aquino, V.H. Steroidal Saponins from the Roots of Solanum Sisymbriifolium Lam. (Solanaceae) Have Inhibitory Activity against Dengue Virus and Yellow Fever Virus. Braz. J. Med. Biol. Res. 2021, 54, e10240. [CrossRef] [PubMed]

111. Castilla, V.; Sepúlveda, C.S.; García, C.C.; Damonte, E.B. Progress for antiviral development in Latin America. In Human Virology in Latin America; Springer: Cham, Switzerland, 2017; pp. 439-460. [CrossRef]

112. Kuhn, R.J.; Zhang, W.; Rossmann, M.G.; Pletnev, S.V.; Corver, J.; Lenches, E.; Jones, C.T.; Mukhopadhyay, S.; Chipman, P.R.; Strauss, E.G.; et al. Structure of Dengue Virus: Implications for Flavivirus Organization, Maturation, and Fusion. Cell 2002, 108, 717-725. [CrossRef]

113. Dengue and Severe Dengue. Available online: https://www.who.int/news-room/fact-sheets/detail/dengue-and-severe-dengue (accessed on 23 May 2021).

114. Poonsiri, T.; Wright, G.S.A.; Solomon, T.; Antonyuk, S.V. Crystal Structure of the Japanese Encephalitis Virus Capsid Protein. Viruses 2019, 11, 623. [CrossRef]

115. Navyashree, V.; Kant, K.; Kumar, A. Natural Chemical Entities from Arisaema Genus Might Be a Promising Break-through against Japanese Encephalitis Virus Infection: A Molecular Docking and Dynamics Approach. J. Biomol. Struct. Dyn. 2021, 39, 1404-1416. [CrossRef]

116. Pulkkinen, L.I.A.; Butcher, S.J.; Anastasina, M. Tick-Borne Encephalitis Virus: A Structural View. Viruses 2018, 10, 350. [CrossRef] [PubMed]

117. Tan, T.Y.; Fibriansah, G.; Kostyuchenko, V.A.; Ng, T.-S.; Lim, X.-X.; Zhang, S.; Lim, X.-N.; Wang, J.; Shi, J.; Morais, M.C.; et al. Capsid Protein Structure in Zika Virus Reveals the Flavivirus Assembly Process. Nat. Commun. 2020, 11, 895. [CrossRef]

118. Yap, M.L.; Klose, T.; Urakami, A.; Hasan, S.S.; Akahata, W.; Rossmann, M.G. Structural Studies of Chikungunya Virus Maturation. Proc. Natl. Acad. Sci. USA 2017, 114, 13703-13707. [CrossRef] [PubMed]

119. Vairo, F.; Haider, N.; Kock, R.; Ntoumi, F.; Ippolito, G.; Zumla, A. Chikungunya: Epidemiology, Pathogenesis, Clinical Features, Management, and Prevention. Infect. Dis. Clin. N. Am. 2019, 33, 1003-1025. [CrossRef]

120. Zhang, Y.-N.; Deng, C.-L.; Li, J.-Q.; Li, N.; Zhang, Q.-Y.; Ye, H.-Q.; Yuan, Z.-M.; Zhang, B. Infectious Chikungunya Virus (CHIKV) with a Complete Capsid Deletion: A New Approach for a CHIKV Vaccine. J. Virol. 2019, 93, e00504-19. [CrossRef] [PubMed]

121. Morozov, V.A.; Lagaye, S. Hepatitis C Virus: Morphogenesis, Infection and Therapy. World J. Hepatol. 2018, 10, 186-212. [CrossRef]

122. Irshad, M.; Dhar, I. Hepatitis C Virus Core Protein: An Update on Its Molecular Biology, Cellular Functions and Clinical Implications. Med. Princ. Pract. 2006, 15, 405-416. [CrossRef] [PubMed]

123. Taherkhani, R.; Farshadpour, F. Global Elimination of Hepatitis C Virus Infection: Progresses and the Remaining Challenges. World J. Hepatol. 2017, 9, 1239-1252. [CrossRef] [PubMed]

124. Hepatitis C. Available online: https:/ / www.who.int/news-room/fact-sheets/detail/hepatitis-c (accessed on 17 July 2021 ).

125. Jackwood, M.W. Review of Infectious Bronchitis Virus around the World. Avian Dis. 2012, 56, 634-641. [CrossRef] [PubMed]

126. Franzo, G.; Legnardi, M.; Tucciarone, C.M.; Drigo, M.; Martini, M.; Cecchinato, M. Evolution of Infectious Bronchitis Virus in the Field after Homologous Vaccination Introduction. Vet. Res. 2019, 50, 92. [CrossRef] [PubMed]

127. Bande, F.; Arshad, S.S.; Omar, A.R.; Hair-Bejo, M.; Mahmuda, A.; Nair, V. Global Distributions and Strain Diversity of Avian Infectious Bronchitis Virus: A Review. Anim. Health Res. Rev. 2017, 18, 70-83. [CrossRef]

128. Cavanagh, D. Coronavirus Avian Infectious Bronchitis Virus. Vet. Res. 2007, 38, 281-297. [CrossRef] [PubMed]

129. Jordan, B. Vaccination against Infectious Bronchitis Virus: A Continuous Challenge. Vet. Microbiol. 2017, 206, 137-143. [CrossRef]

130. Heydari, H.; Golmohammadi, R.; Mirnejad, R.; Tebyanian, H.; Fasihi-Ramandi, M.; Moosazadeh Moghaddam, M. Antiviral Peptides against Coronaviridae Family: A Review. Peptides 2021, 139, 170526. [CrossRef] [PubMed]

131. Gao, Y.; Sun, S.-Q.; Guo, H.-C. Biological Function of Foot-and-Mouth Disease Virus Non-Structural Proteins and Non-Coding Elements. Virol. J. 2016, 13, 107. [CrossRef] [PubMed]

132. Grubman, M.J.; Baxt, B. Foot-and-Mouth Disease. Clin. Microbiol. Rev. 2004, 17, 465-493. [CrossRef] 
133. Lloyd-Jones, K.; Mahapatra, M.; Upadhyaya, S.; Paton, D.J.; Babu, A.; Hutchings, G.; Parida, S. Genetic and Antigenic Characterization of Serotype O FMD Viruses from East Africa for the Selection of Suitable Vaccine Strain. Vaccine 2017, 35, 6842-6849. [CrossRef] [PubMed]

134. Bharat, T.A.M.; Noda, T.; Riches, J.D.; Kraehling, V.; Kolesnikova, L.; Becker, S.; Kawaoka, Y.; Briggs, J.A.G. Structural Dissection of Ebola Virus and Its Assembly Determinants Using Cryo-Electron Tomography. Proc. Natl. Acad. Sci. USA 2012, 109, 4275-4280. [CrossRef] [PubMed]

135. Muñoz-Fontela, C.; McElroy, A.K. Ebola Virus Disease in Humans: Pathophysiology and Immunity. Marburg Ebolaviruses 2017, 411, 141-169. [CrossRef] [PubMed]

136. Yamaoka, S.; Ebihara, H. Pathogenicity and Virulence of Ebolaviruses with Species- and Variant-Specificity. Virulence 2021, 12, 885-901. [CrossRef]

137. V'kovski, P.; Kratzel, A.; Steiner, S.; Stalder, H.; Thiel, V. Coronavirus Biology and Replication: Implications for SARS-CoV-2. Nat. Rev. Microbiol. 2021, 19, 155-170. [CrossRef] [PubMed]

138. Vijayanand, P.; Wilkins, E.; Woodhead, M. Severe Acute Respiratory Syndrome (SARS): A Review. Clin. Med. 2004, 4, 152-160. [CrossRef] [PubMed]

139. Beig Parikhani, A.; Bazaz, M.; Bamehr, H.; Fereshteh, S.; Amiri, S.; Salehi-Vaziri, M.; Arashkia, A.; Azadmanesh, K. The Inclusive Review on SARS-CoV-2 Biology, Epidemiology, Diagnosis, and Potential Management Options. Curr. Microbiol. 2021, 78, 1099-1114. [CrossRef] [PubMed]

140. Alnuqaydan, A.M.; Almutary, A.G.; Sukamaran, A.; Yang, B.T.W.; Lee, X.T.; Lim, W.X.; Ng, Y.M.; Ibrahim, R.; Darmarajan, T.; Nanjappan, S.; et al. Middle East Respiratory Syndrome (MERS) Virus-Pathophysiological Axis and the Current Treatment Strategies. AAPS PharmSciTech 2021, 22, 173. [CrossRef] [PubMed]

141. Umakanthan, S.; Chattu, V.K.; Ranade, A.V.; Das, D.; Basavarajegowda, A.; Bukelo, M. A Rapid Review of Recent Advances in Diagnosis, Treatment and Vaccination for COVID-19. AIMS Public Health 2021, 8, 137-153. [CrossRef] [PubMed] 